University of Nebraska - Lincoln

DigitalCommons@University of Nebraska - Lincoln

Faculty Publications in Educational

Administration

Educational Administration, Department of

2020

Shared Leadership for Learning in Denver's Portfolio Management

Model

A. Chris Torres

Katrina Bulkley

Taeyeon Kim

Follow this and additional works at: https://digitalcommons.unl.edu/cehsedadfacpub

Part of the Educational Administration and Supervision Commons

This Article is brought to you for free and open access by the Educational Administration, Department of at DigitalCommons@University of Nebraska - Lincoln. It has been accepted for inclusion in Faculty Publications in Educational Administration by an authorized administrator of DigitalCommons@University of Nebraska - Lincoln. 
Published in Educational Administration Quarterly 56:5 (2020), pp. 819-855;

doi: 10.1177/0013161X20906546

Copyright (c) 2020 A. Chris Torres, Katrina Bulkley, and Taeyoeon Kim. Used by permission.

First published April 1, 2020.

\title{
Shared Leadership for Learning in Denver's Portfolio Management Model
}

\author{
A. Chris Torres, ${ }^{1}$ Katrina Bulkley, ${ }^{2}$ and Taeyeon $\mathrm{Kim}^{1}$
}

1. Michigan State University, East Lansing, Michigan, USA

2. Montclair State University, Montclair, New Jersey, USA

Corresponding author - A. Chris Torres, College of Education, Michigan State University, 620 Farm Lane, Room 433, East Lansing, MI 48824, USA, email ctorres@msu.edu

\begin{abstract}
Purpose: This study examines how district governance and different school contexts in Denver's portfolio management model affect shared leadership for learning. We define this as shared influence on instructional leadership and schoolwide decision making, which research suggests have strong ties to student achievement and teacher commitment. Method: We analyze interview data from 53 administrators, teacher leaders, and teachers in eight case study schools and teacher surveys in 48 schools. In both data sets, we purposively sampled based on variance in school performance ratings and by school type (e.g., traditional public, stand-alone charter, charter management organization [CMO], and innovation schools). Findings: We find that perceptions of shared instructional leadership were generally high across the school contexts, though $\mathrm{CMO}$ and innovation schools had the highest perceptions in both the survey and case study data. Schools varied substantially in shared decision making, but innovation schools had higher average scores than other school models. Centralized policies and supports, alongside organizational visions spanning networks of schools, helped explain the enactment of shared leadership for learning. For example, schools within Denver's "innovation" network shared a common vision of teacher empowerment, while CMOs that had more prescribed policies and practices across their schools had lower reported levels of shared decision making. Implications for Research and Practice: Portfolio management models that prioritize school-based autonomy and choice between different kinds of schools are proliferating in urban areas. Our study helps explain why and how shared leadership for learning differs between school models and explores important implications for this variation.
\end{abstract}


Keywords: teacher influence, shared leadership, schoolwide decision making, instructional leadership, portfolio management models, charter management organizations

\section{Introduction}

In recent years, a variety of urban school systems have shifted from centralized oversight under a traditional school district to portfolio management models (PMMs), in which central offices oversee schools operating under varied governance conditions, such as autonomous, privately managed schools, and charter schools (Bulkley, Henig, \& Levin, 2010). Central to the idea of the PMM is the push to provide diverse and differentiated school options that offer schools and families more choice to make strategic decisions about where students can go to school and how to best meet their needs. For example, Denver Public Schools (DPS) offers a range of school options in their "portfolio." These include traditional public schools (TPSs) operated by the district, semiautonomous "innovation" schools that submit applications to gain autonomy from specific state and district policies, autonomous stand-alone charter schools that are authorized by DPS and overseen by a charter board, and charter management organization (CMO) affiliated charter schools that (while also authorized by DPS) are overseen and supported by a CMO central office (Tushman et al., 2016). Although DPS emphasizes academic achievement in its accountability framework, some of these school types have substantial autonomy to provide diverse school visions and programming across Denver.

At the same time, a growing body of research suggests that shared and collaborative leadership approaches that include and empower teachers can bolster teacher commitment and effectiveness (e.g., Sebastian et al., 2016; Torres, 2019). This makes Denver an interesting context to study since the district adopted a teacher leadership and collaboration initiative in 2013-2014, which started with 14 schools participating in 2013-2014 and expanded to 71 schools by the time of our study (2016-2017). In this model, DPS provides training to teacher leaders who spend about half their time in the classroom and the other half providing supports to other teachers such as leading teams, coaching, evaluation, collaborative planning, and reviewing student work. Alongside initiatives that emphasize teacher leadership focused on instruction, PMMs emphasize school-based autonomy, theoretically giving educators in schools (including teachers) the potential to exert greater control over various kinds of decision making.

This study focuses on how school and governance contexts affect shared leadership for learning, which we define as the combination of collaborative influence on instructional leadership and schoolwide decisions. We analyzed survey data from 48 schools across Denver and interviews with 53 teachers and leaders in eight schools to answer the following questions:

1. How is shared leadership for learning enacted in these different school models?

2. What conditions influence the enactment of shared leadership for learning in these schools? 


\section{Portfolio Management Models}

There is very little empirical literature on PMMs given their recent emergence in urban educational systems (Bulkley, Henig, \& Levin, 2010). PMMs shift the relationship between the central office (we refer to the Denver central office, in keeping with local norms, as DPS) and schools in ways that should theoretically affect leadership behavior by imposing performance-based accountability while allowing substantiative autonomy at the school level (Hill et al., 2013). First, all schools in Denver operate under the School Performance Framework (SPF) which consists of multiple measures, including academic growth, academic proficiency, college and career readiness, student engagement, enrollment rates, and parent satisfaction. Academic growth receives the most weight in the SPF calculation. If schools do not meet academic goals, they can be closed and replaced. Denver did this frequently in the early years of the PMM (Torres, Bulkley, \& McCotter, 2018).

PMMs also allow different kinds of schools that have a range of autonomies, with charter schools having the most autonomy from collective bargaining agreements and state and district policies. For example, PMMs may provide leaders with more flexibility to hire or fire teachers, choose curricular approaches, control budgets and school schedules, and select approaches for educators' professional learning and other supports whether from the district or from outside organizations. A core assumption is that the flexibility offered via autonomous governance models will result in schools that are more accountable to parents and the district and will put pressure on leaders to use their added freedom in order to more effectively pursue educational improvement (Hill et al., 2013; Lake \& Hill, 2009). While prior work describes the PMM context, there is little empirical work examining how and why a PMM influences teachers, leaders, and the processes of teaching and learning.

Three quasi-experimental studies of New York, post-Katrina New Orleans, and the Los Angeles Unified School District's portfolio models found generally positive effects on student achievement (D. N. Harris \& Larsen, 2016; Kemple, 2011; Strunk et al., 2016). However, given the substantial variation in the specific interpretation of the PMM idea within different cities, these studies highlighted the need to understand how and why such effects might be achieved within each specific context. Other recent studies looked at the influence of the common enrollment system on families' choices in Denver (Denice \& Gross, 2016) and variation in student achievement and behavior in different school types within the "portfolio" of New Orleans schools (McEachin et al., 2016). McEachin et al. (2016) found that nationally and locally "networked" charter schools had particularly positive effects compared with independent or stand-alone charters and direct-run TPSs. They argue that research should study the benefits of working in a networked charter school compared with nonnetworked schools, and point to the need to understand variation between the different kinds of school models within a PMM sector.

In an article highlighting challenges of decentralized systems like New Orleans' portfolio system to address system-level problems, Buerger and Harris (2015) posit: "Decentralization with large numbers of relatively small organizations requires coordination, which may make it difficult to solve problems" (p. 1247). As they point out, some degree of centralization in a portfolio system may be beneficial in terms of creating efficiencies and coordinating supports across a set of schools, which may help explain the results from the 
study conducted by McEachin et al. (2016). Given the qualitative and school-level nature of our study, it is positioned to contribute to the question of how and why centralized or decentralized structures affect teachers/leaders in the specific context of Denver's PMM. In particular, we focus on how differences in context affect shared instructional leadership and schoolwide decision making.

\section{School Models in a PMM}

One major difference in school contexts has to do with the school types offered within a portfolio. Here, we highlight these differences as they relate to shared leadership for learning, focusing on the models that are theoretically more "autonomous" from state and district policies.

\section{Charter management organizations}

An emergent body of literature examines "networked" CMO models and their practices. One theme of this work, as it relates to shared leadership for learning, involves a noted tension in terms of collaboration and control of management decisions between public (e.g., teachers; districts) versus private interests and providers (Bulkley, 2005; DiMartino, 2014; Gold et al., 2007). In the context of CMOs, studies highlight how teachers and school leaders can have little autonomy to make decisions related to curriculum, instruction, discipline, and assessment in part because some CMO models feel they have developed a set of best practices that work to produce student achievement gains (Torres, 2014; DiMartino, 2014; Furgeson et al., 2012). Thus, quantitative studies using nationally representative Schools and Staffing Survey data and qualitative case studies show that CMO teachers tend to have less influence over school and classroom decisions compared with other standalone charter models, and that this diminished autonomy is linked to turnover (Torres, 2014; Roch \& Sai, 2018).

\section{Stand-alone charter schools}

By contrast, studies of stand-alone charter schools highlight the centrality of management responsibilities for charter leaders, who must create systems and make decisions about things normally directed by a central office such as HR (human resource) systems and facilities (Torres, Bulkley, \& McCotter, 2018; Bickmore \& Dowell, 2011; Cravens et al., 2012). This wide range of autonomy extends to instructional leadership decisions but can lead to work overload, making it difficult for principals to spend time on instructional leadership (Carpenter \& Peak, 2013). In short, shared leadership for learning may depend and vary (more so than CMOs) based on each individual principal's capacity and the specific mission and vision for the school.

\section{Innovation schools}

Innovation schools in Denver, as one example of districtrun autonomous schools, must submit applications to the district to gain autonomy from specific district policies, for example, they may waive requirements to use particular scheduling, personnel, or curriculum mandates (Gigliotti, 2019). One study used a difference-in-difference design to see whether a change to innovation status improved student achievement and found positive 
effects on end of year standardized exams in Math, Reading, and Writing (Gigliotti, 2019). While it is theorized that managerial autonomy is responsible for these positive effects, our study can help explain how or why this may or may not be the case.

\section{Shared Leadership for Learning}

We ground this study in two central aspects of leadership for learning: shared instructional leadership, which emphasizes the ways in which leaders, teachers, and others work together to support instructional improvement; and shared schoolwide decision making, which incorporates the ways that influence is shared within a building. While we treat these as distinct aspects of leadership for learning, they are potentially intertwined as the extent of each may shape the other. For example, literature suggests that using strategies to share decision making with teachers is important for establishing communities of practice and norms for teacher collaboration and data use (Ingersoll et al., 2018). Shared decision-making processes can engage teachers as professionals, and therefore enhance teachers' motivation and commitment to instructional improvement approaches. Indeed, some argue that shared decision making requires effective instructional leadership because structures to empower teachers can feel like a waste of time if they are not aligned to instructional or school improvement in some meaningful way (Bernd, 1992). Despite these links, and as we noted in the previous section, some elements of shared leadership for learning may be prioritized in some school models in a PMM over others (e.g., shared instructional leadership but not shared decision making in CMOs). Yet both of these aspects of leadership for learning have important ties to issues of student achievement. Therefore, we are particularly interested in how the broader governance context is connected with school-based shared leadership for learning (as shown in Figure 1).

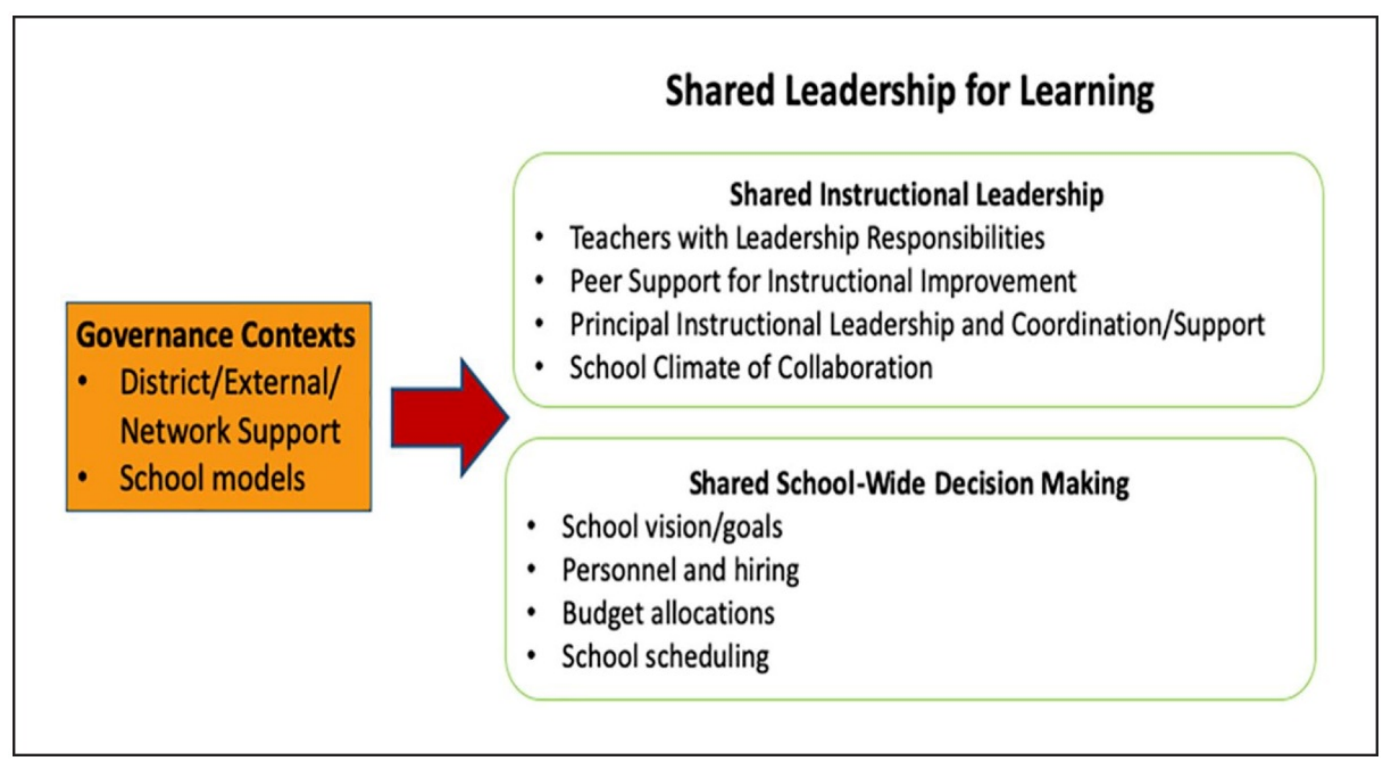

Figure 1. Conceptual Framework 
While researchers have identified different leadership typologies (e.g., distributed leadership, instructional leadership, shared instructional leadership, leadership for learning, and collective leadership), we note that a helpful conceptual comparison shows substantial overlap across different leadership styles (Urick \& Bowers, 2014). Therefore, we use the term "shared leadership for learning" to indicate the principal's role in sharing and facilitating influence on instruction and other leadership decisions throughout the school.

\section{Shared Instructional Leadership}

Instructional leadership literature focuses on leaders' direct influence on instruction (Leithwood \& Jantzi, 2008; Marks \& Printy, 2003; Urick, 2016). This literature generally describes how principals facilitate an environment that supports continual professional learning (the instructional climate) and the steps they take to engage with individual teachers about their own growth (instructional actions; Grissom et al., 2013; Louis, Leithwood, et al., 2010). Literature on instructional actions describes how leaders engage with issues of curriculum and instruction and conduct informal or formal walkthroughs, evaluation, and teacher coaching, though coaching and program development show the most robust relationship to positive achievement gains (Grissom et al., 2013).

However, scholars criticize conceptualizations of instructional leadership that reinforce a top-down approach in which principals "lead" and teachers are docile followers (Marks \& Printy, 2003; Neumerski, 2013; Sheppard, 1996). More recent discussions of instructional leadership shift toward indirect and collaborative perspectives by empowering teachers to engage in decision making within schools. Shared instructional leadership focuses on principals' efforts to integrate the expertise of teachers and share leadership roles around instruction (Marks \& Printy, 2003). Thus, principals influence student learning by fostering a strong professional learning community and creating a robust instructional climate (e.g., see Louis, Dretzke, et al., 2010, for a review). Principals accomplish this is by strategically sharing influence with teachers, fostering meaningful teacher leadership, and facilitating teacher collaboration and data use around schoolwide goals (Allensworth \& Hart, 2018). These elements comprise our conceptual framework.

Teacher leadership

In addition to the focus on principals' leadership, recent studies examine the value of identifying master teachers who can coach teacher teams (similar to the approach that DPS takes with its teacher leadership model; Backes \& Hansen, 2018), and working in teacher teams in ways that foster feelings of professional efficacy and community (Allensworth \& Hart, 2018). These and other studies find that robust teacher leadership is strongly related to student learning gains. For example, Ingersoll et al. (2018) analyzed the Teaching, Empowering, Leading, and Learning Survey from 2008 to 2014 and found that schools with higher levels of teacher leadership as measured by input on various aspects of instruction and planning had significantly higher student achievement even after controlling for school characteristics, including measures of poverty. Importantly, measures of shared decision making were also included in that study's analysis of teacher leadership. 
Teacher collaboration and peer support for instructional improvement

Although not all collaboration is equal, existing literature demonstrates the importance of productive teacher collaboration around instruction. At a basic level, teachers need both time and a consistent structure or routine (e.g., instructional rounds; data team meetings; etc.) to support and influence peers' continual instructional improvement. Productive collaboration happens in alignment with schoolwide improvement goals, and was most strongly related to student achievement when perceived quality is high and when focused on analyzing student data or curriculum to develop appropriate instructional responses (Ronfeldt et al., 2015). At the same time, scholars note that an effective culture of collaboration depends on a high degree of teacher-teacher trust (e.g., Hallam et al., 2015). Thus, we report these measures of trust in our survey data.

\section{Principal coordination and expectation setting}

The effectiveness of shared instructional leadership depends on how coherently it is structured. Principals play an important role in coordinating structures for teacher collaboration, development, and learning through effective communication and resource allocation (Johnson et al., 2014). Due to their unique formal authority across the school, principals are charged with setting the direction and expectations to structure various teacher-learning opportunities and organizational systems. For our purposes, we focused on identifying the presence of formal structures for collaboration (e.g., professional learning communities, peer coaching) and teacher influence on instruction (e.g., teacher leader roles), as well as how these structures were perceived within our case schools.

\section{Shared Schoolwide Decision Making}

Researchers increasingly argue that sharing influence with teachers on major decisions about how a school operates and uses its various resources is critical for improving school climate and student achievement (Ingersoll et al., 2018; Louis, Dretzke, et al., 2010; Sebastian et al., 2016). Sebastian et al. (2016) used structural equation modeling to examine the influence of principals and teacher leaders in elementary schools and found that principals influenced student achievement through improving school climate. They find teacher influence to be especially critical: "principals' influence on school climate comes almost entirely through teacher influence in decision making ... [giving greater influence] may be the most effective strategy for school principals to influence student achievement" (Sebastian et al., 2016, pp. 91-92). How influence is shared and whether such processes meet the specific needs of the school context clearly matters. While shared instructional leadership is important, researchers have also found that sharing influence in decisions that fall outside of instruction can communicate trust/respect for teachers and enhance their sense of empowerment and motivation to work toward shared goals (e.g., Bogler \& Nir, 2012; Lee \& Nie, 2014).

Vision and goals

Syntheses of leadership research suggest that the link between leadership, instruction, and achievement is strongest when vision and goals are clearly defined and have an explicit academic/learning focus (Hallinger \& Heck, 1996; Miles \& Louis, 1990; Robinson et al., 
2008). When leaders "operationalize and steward" academic goals well (Murphy et al., 2007), shared goals motivate all staff to work in consistent directions and limit "staff attention to a narrower range of desired ends and scope of activities ... [helping] to clarify what we will do and what we will not do" (Hallinger, 2011, pp. 129-130). Whether and how teachers are involved in conversations around goal and vision setting has important implications for their motivation (Cooper et al., 2016; Little, 2006; Wood, 2007). However, this also depends on the school context, since teachers may explicitly choose to join a school with a highly defined instructional model and express less desire for involvement in having input into the vision and goals for this model, particularly if it involves increased demands on their time.

Personnel, budget, scheduling

Compared with lower-achieving schools, higher-achieving schools tend to involve teachers and others in a range of critical decisions that have traditionally been made by formal school leaders (Leithwood \& Mascall, 2008; Louis, Leithwood, et al., 2010). Such teacher involvement in decision making can foster trust and strong, collegial relationships (Gronn, 2000; A. Harris et al., 2007). Distributing leadership influence in these areas is positively associated with teachers' job satisfaction (Ni et al., 2018), a finding that holds true using international 2013 Teaching and Learning International Survey data and controlling for individual teacher and school level variables (Torres, 2019).

\section{Governance and Shared Leadership for Learning}

Finally, although a growing body of work highlights whether, how, and why teacher influence is critical, much of it neglects to describe the role of the governance context (Hallinger, 2011, 2018; Spillane, 2006). The district governance context can have a strong influence on leaders and the enactment of shared leadership for learning-DPS's accountability system undoubtedly influences how principals approach leadership. For example, accountability goals come preestablished rather than being set internally or collaboratively, which could affect how principals navigate vision and goal setting and the degree to which they involve teachers.

Moreover, there is a philosophical tension regarding how districts should approach governance and school support in a portfolio system. Lake and Hill (2009) argue that while traditional districts measure performance, they have few mechanisms to improve schools that are chronically low performing and need to create ways to replace and close schools. To do this, they argue that portfolio districts should partner with outside providers to support schools rather than provide it themselves so that they do not "risk blurring the lines of responsibility and accountability" (Lake \& Hill, 2009, p. 25).

However, scholarship in the past two decades suggests that school districts can play a critical role in leading instructional change and should work to improve their internal capacity to support school improvement (Augustine et al., 2009; Gallucci \& Swanson, 2006; Hatch et al., 2016; Honig et al., 2017; Honig \& Rainey, 2014). These studies highlight the importance of shared learning opportunities and outcomes for leaders and teachers organized by the district, underscoring how structured support from central offices can help schools achieve large-scale changes and improvement. For instance, Rorrer and colleagues 
(2008) reviewed the literature on how districts advance achievement and equity, identifying four critical roles they play: providing instructional leadership, reorienting the organization, establishing policy coherence, and maintaining an equity focus.

In terms of this first role, for example, Honig (2012) found meaningful learning occurring for principals when the district provided direct and ongoing support for instructional leadership through approaching the learning as joint work and using strategies such as modeling (e.g., leadership thinking and actions). In contrast with Lake and Hill's (2009) contention that outside providers take on this work, Honig (2012) further argued, "this analysis suggests the promise of central offices not contracting out to support principals' instructional leadership" (p. 767). This highlights a tension between the idea of developing the capacity of a district as an organization to support leadership and the more hands-off approach suggested by some portfolio advocates.

\section{Method}

\section{Study Context: Denver's Portfolio Management Model}

In 2016-2017, at the time of our data collection, the central office of the DPS oversaw a portfolio of 211 schools serving about 92,000 students that included 95 TPSs, 56 charter schools (37 of which were run by CMOs and 19 were stand-alone charters), 56 "innovation" schools, and 12 magnet schools. A small number of innovation schools (four) had banded together to form the Luminary Learning Network (LLN); two of the three innovation schools in our sample were part of the LLN along with one stand-alone charter, two CMO schools, and two TPSs. DPS sought to enable positive relationships between schools and the central office regardless of school type; this effort included greater centralization than found in some other PMMs (Torres, Bulklry, Hashim, et al, 2018).

The four LLN schools have distinct foci but also share a common vision that centers collaboration within and across the four schools and with DPS. Part of the larger vision of the LLN is to distribute leadership and magnify the voices of teachers and school leaders. As two original contributors to the idea of the LLN put it: "The guiding vision was for radical empowerment of the educators closest to the students. So we began simply by asking fundamental questions about who gets to make key decisions about new hires, schedule, curriculum, culture, and budget" (Seawell \& Alessi, 2018, p. 1). Unlike the CMOs we studied, the LLN does not have a specific school model but instead serves as both support for schools in the network and advocate for increased autonomy for those schools from DPS.

\section{Data Collection and Sampling}

The data for this study comes from a large mixed-method comparative study of three PMMs in Denver, New Orleans, and Los Angeles. By drawing on school case studies and teacher surveys, we are able to take a deeper look at practices within a small number of schools while having the benefit of breadth through surveys (Creswell \& Clark, 2007; Yin, 2013).

Eight Denver qualitative school case studies were purposively sampled based on variance in their performance rating and the type of school (e.g., $\mathrm{CMO}$, stand-alone charter, traditional public, and semiautonomous - see Table 1). In each case study school, two researchers conducted a 1-day site visit. During these visits, we interviewed administrators, 
teacher leaders, and three to five teachers for a total of 53 interviews. In our interviews, we sought to understand participants' perspectives on a wide range of school practices. Our semistructured interview protocols included questions about instructional practices, teacher collaboration, relationships between teachers and leaders, and whether, why, and how teachers had input in leadership decisions and schoolwide practices. Interviews were transcribed and ranged in length from 20 to 87 minutes.

\begin{tabular}{|c|c|c|c|c|c|c|c|c|}
\hline \multirow[b]{2}{*}{$\begin{array}{l}\text { School } \\
\text { name }\end{array}$} & \multirow[b]{2}{*}{$\begin{array}{l}\text { Governance } \\
\text { model }\end{array}$} & \multirow[b]{2}{*}{ Grades } & \multicolumn{4}{|c|}{ Student demographics (2016-2017) } & \multirow[b]{2}{*}{$\begin{array}{l}\text { School } \\
\text { perfor- } \\
\text { mance } \\
\text { level }^{\text {a }}\end{array}$} & \multirow[b]{2}{*}{$\begin{array}{l}\text { Number of } \\
\text { interviews } \\
\text { (participants) }\end{array}$} \\
\hline & & & $\begin{array}{l}\text { Students } \\
\text { of } \\
\text { color } \\
(\%)\end{array}$ & $\begin{array}{c}\text { FRL } \\
(\%)\end{array}$ & $\begin{array}{l}\text { ELL } \\
(\%)\end{array}$ & $\begin{array}{l}\text { SPED } \\
(\%)\end{array}$ & & \\
\hline Blue & $\begin{array}{l}\text { Traditional } \\
\text { public }\end{array}$ & ECE-5 & 80 & 74.8 & 49.1 & 6.8 & Green & $\begin{array}{l}5 \text { ( } 4 \text { teachers and } \\
1 \text { leader) }\end{array}$ \\
\hline Brown & $\begin{array}{l}\text { Traditional } \\
\text { public }\end{array}$ & ECE-5 & 92 & 89.7 & 21.8 & 12.6 & Yellow & $\begin{array}{l}7 \text { ( } 3 \text { teachers, } 3 \\
\text { leaders, and } 1 \text { prin- } \\
\text { cipal supervisor) }\end{array}$ \\
\hline Cerise & $\begin{array}{l}\text { Innovation } \\
\text { (part of } \\
\text { luminary } \\
\text { learning } \\
\text { network) }\end{array}$ & ECE-5 & 95 & 89.9 & 46.9 & 15.2 & Yellow & $\begin{array}{l}5 \text { ( } 3 \text { teachers, } \\
1 \text { leader, and } \\
1 \text { LLN director) }\end{array}$ \\
\hline Green & Innovation & K-5 & 18 & 9.5 & 2.5 & 5.3 & Green & $\begin{array}{l}7 \text { ( } 4 \text { teachers, } 2 \\
\text { leaders, and } 1 \text { prin- } \\
\text { cipal supervisor) }\end{array}$ \\
\hline Khaki & $\begin{array}{l}\text { Charter, } \\
\text { part of } \\
\text { network }\end{array}$ & $5-8$ & 95 & 92.1 & 63.7 & 8.6 & Red & $\begin{array}{l}7 \text { ( } 4 \text { teachers, } 2 \\
\text { leaders, and } 1 \text { prin- } \\
\text { cipal supervisor) }\end{array}$ \\
\hline Purple & $\begin{array}{l}\text { Stand-alone } \\
\text { Charter }\end{array}$ & $6-8$ & 55 & 48.6 & 20.4 & 10.7 & Green & $\begin{array}{l}8 \text { ( } 3 \text { teachers, } 5 \\
\text { leaders, principal } \\
\text { supervisor) }\end{array}$ \\
\hline Teal & $\begin{array}{l}\text { Small } \\
\text { CMO } \\
\text { Charter }\end{array}$ & K-5 & 92 & 89.4 & 71.2 & 7.5 & Green & $\begin{array}{l}7 \text { ( } 4 \text { teachers, } 2 \\
\text { leaders, and } 1 \text { prin- } \\
\text { cipal supervisor) }\end{array}$ \\
\hline Viridian & Innovation & ECE-5 & 65 & 51.3 & 34.2 & 11.3 & Green & $\begin{array}{l}7 \text { (5 teachers and } \\
2 \text { leaders) }\end{array}$ \\
\hline
\end{tabular}

Note: We attempted to recruit schools with a wider range of performance but were unsuccessful in recruiting a school that fell into the "Orange" category. Red = accredited on probation; Orange = accredited on priority watch; Yellow = accredited on watch; Green = meets expectations; Blue = distinguished.

aResults from school performance framework report. For details, http://spf.dpsk12.org/wp-content/uploads/ 2018/10/SPF-Report-Guide_ENGLISH_2018.pdf.

Concurrently with qualitative data collection, we conducted teacher surveys, seeking a stratified sample that varied intentionally based on (a) governance type (i.e., traditional, charters, and innovation schools) and (b) academic performance. In total, 686 DPS teachers in 48 schools responded to the survey for a response rate of $52.5 \%$. In our analysis for this article, we excluded 109 teachers in self-contained magnet schools because our case studies 
did not include this type of school. Thus, our final sample included 577 teachers from four school governance models: traditional public (262), innovation (158), CMO charters (92), and stand-alone charters (65).

\section{Data Analysis}

\section{School case studies}

We used a method for analyzing, comparing, and contrasting multiple case study data called DIVE, which entails four stages of analysis: Describe, Integrate, Visualize, and Expand (Bush-Mecanas \& Marsh, 2018). This approach involves "cycically analyzing case-ordered metamatrix displays - tables with cases as rows and theoretical or empirically driven constructs as columns" and creating visual or conceptual diagrams to understand patterns among variables (Bush-Mecanas \& Marsh, 2018, p. 35). For the first stage of analysis (describe), we started by reducing the large amount of interview data using a broad "leadership" code to capture all data where leaders or teachers discussed matters related to overall leadership, instruction, student achievement, and influences on teaching and leadership as well as perceptions of how the school or governance context (e.g., accountability) influenced leadership and instruction. During this process, we met regularly as a team to norm and check for consistency in coding to ensure the most relevant data were being captured.

The second round of analysis involved coding in alignment with the conceptual framing. We first coded these data in NVivo then integrated relevant quotes in a matrix in Excel that allowed us to compare and create categories capturing important findings within and across the case study schools based on the qualities of shared instructional leadership and shared schoolwide decision making included in our conceptual framework. The components both (a) have been identified as important in the literature and (b) were well represented in data that we collected (Bush-Mecanas \& Marsh, 2018; Miles \& Huberman, 1994).

Next, we sought to visualize where each school case stood on relevant criteria from our conceptual frame (see Figure 2). We did this by setting thresholds using two primary criteria: (a) presence of the structure and (b) perceived quality of the structure. For example, in assessing teacher collaboration within a case school, we looked for examples of participants discussing a structure that would enable collaboration (e.g., data team meetings) and whether/how they discussed this structure as enhancing or not enhancing the quality of instruction. Considering teacher input, we looked for whether teachers had formal structures for input (e.g., presence on teacher committees) and the extent to which this input was perceived to influence final decisions. In some cases, structures were present, but teachers noted significant problems with them: for instance, serving on committees but describing input as not really mattering to final decisions. To strengthen trustworthiness of our findings, we independently rated each case study school, assigning 0,1 , or 2 points depending on our criteria: structure and perceived quality (a rating of " 2 " would illustrate, for example, that collaborative structures were present and perceived highly by teachers). We met three times to discuss rating discrepancies, using raw data as sources of evidence to substantiate our ratings until we unanimously agreed. 


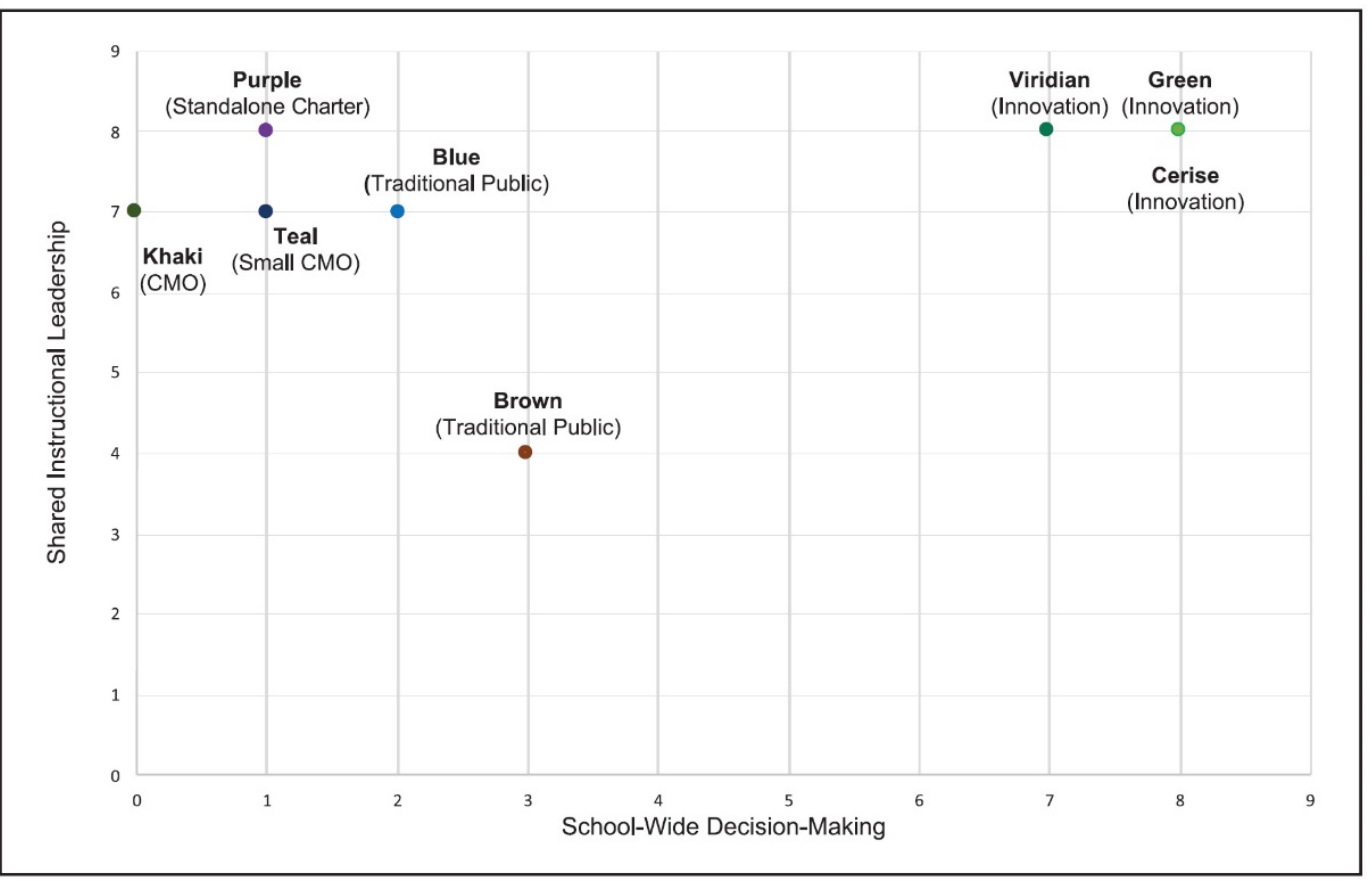

Figure 2. Case Schools and Shared Leadership for Learning Visual Matrix. Note: $\mathrm{CMO}=$ charter management organization.

Finally, we expanded our analysis by returning to our data and discussing the three previous stages to ask "why" questions. For example, why did innovation schools have strong ratings on both elements of shared leadership for learning and charters have relatively low ratings on schoolwide decision making? How did context inform these differences? This final step helped us generate tentative explanations and explain variation in our cases.

\section{Survey data analysis}

To explore the patterns we found within our school case study analysis, we analyzed teacher survey data collected in DPS. We conducted this exploratory analysis to see if trends in teachers' responses mirrored what we found in school case studies. We selected survey items that mirrored our conceptual framework: teachers' responses about (a) the frequency of their participation in peer-supported activities for instructional improvement, (b) instructional leadership and coordination/support of their own principal, (c) school climate of collaboration, and (d) levels of influence they have in making schoolwide decisions.

We used weights for our analysis to account for sampling and response bias; this enabled us to obtain estimates that would be representative of the broader population of teachers in different school model types and performance categories in Denver (Lavallée \& Beaumont, 2015). The weights were developed based on school model and performance level given the fact that there were significant differences between respondents and nonrespondents in the survey data and that these two criteria were used for sampling schools for the teacher survey. We reported weighted analysis results in our findings to enable us 
to better understand patterns of the population. Table 2 reports the survey items used and descriptive statistics resulting from both weighted analyses. For each item, we conducted analysis of variance with a post hoc test using the Hochberg procedure. ${ }^{1}$ We used the Hochberg's GT2 given the condition of different sample sizes across the four groups (Pereira et al., 2015).

Table 2. Survey Items and Descriptive Statistics (Weighted Response)

\begin{tabular}{|c|c|c|c|c|c|}
\hline Category ${ }^{a}$ & Variable & Description of survey items & $N$ & $M$ & $S D$ \\
\hline \multirow{4}{*}{$\begin{array}{l}\text { Peer support for } \\
\text { instructional } \\
\text { improvement } \mathrm{t}^{\mathrm{b}} \\
\text { (monthly basis, \%) }\end{array}$} & $\begin{array}{l}\text { Analyze } \\
\text { data }\end{array}$ & $\begin{array}{l}\text { Met with other teachers at our school to } \\
\text { analyze student achievement data or } \\
\text { student work }\end{array}$ & 4,641 & 0.65 & 0.48 \\
\hline & $\begin{array}{l}\text { Discuss } \\
\text { practice }\end{array}$ & $\begin{array}{l}\text { Met with other teachers at our school to } \\
\text { discuss and improve our practice }\end{array}$ & 4,655 & 0.74 & 0.44 \\
\hline & Meet coach & $\begin{array}{l}\text { Met with an instructional coach to plan for } \\
\text { instruction }\end{array}$ & 4,540 & 0.58 & 0.49 \\
\hline & $\begin{array}{c}\text { Student } \\
\text { needs }\end{array}$ & $\begin{array}{l}\text { Met with other school staff to discuss the } \\
\text { social or behavioral needs of individual } \\
\text { students }\end{array}$ & 4,653 & 0.68 & 0.47 \\
\hline \multirow{6}{*}{$\begin{array}{l}\text { Principal } \\
\text { instructional } \\
\text { leadership and } \\
\text { coordination/ } \\
\text { support }\end{array}$} & Standards & Sets high standards for teaching & 4,452 & 3.24 & 0.75 \\
\hline & Resource & $\begin{array}{l}\text { Routinely helps us allocate resources, } \\
\text { including time, money, and personnel, to } \\
\text { support our improvement }\end{array}$ & 4,391 & 2.91 & 0.83 \\
\hline & PD & $\begin{array}{l}\text { Ensures that teachers have sufficient time } \\
\text { for professional development }\end{array}$ & 4,454 & 2.88 & 0.80 \\
\hline & Quality & $\begin{array}{l}\text { Actively monitors the quality of instruction } \\
\text { in our school }\end{array}$ & 4,413 & 2.80 & 0.88 \\
\hline & Coaching & $\begin{array}{l}\text { Provides high-quality instructional coaching } \\
\text { to teachers }\end{array}$ & 4,285 & 2.64 & 0.92 \\
\hline & $\begin{array}{l}\text { Account- } \\
\text { able }\end{array}$ & $\begin{array}{l}\text { Holds teachers accountable for using data to } \\
\text { inform/guide their practice }\end{array}$ & 4,341 & 3.06 & 0.78 \\
\hline \multirow[t]{7}{*}{$\begin{array}{l}\text { School climate of } \\
\text { collaboration }\end{array}$} & Share & $\begin{array}{l}\text { Staff do not share materials or ideas with } \\
\text { one another (Reverse coded) }\end{array}$ & 4,659 & 3.27 & 0.66 \\
\hline & Advice & $\begin{array}{l}\text { Teachers turn to one another for } \\
\text { consultation and advice }\end{array}$ & 4,653 & 3.26 & 0.63 \\
\hline & Trust & Teachers trust each other & 4,656 & 3.09 & 0.69 \\
\hline & Discuss & $\begin{array}{l}\text { It's OK to discuss feelings, worries, and } \\
\text { frustrations with other teachers }\end{array}$ & 4,651 & 3.03 & 0.74 \\
\hline & Lead & $\begin{array}{l}\text { Teachers respect other teachers who take the } \\
\text { lead in school improvement efforts }\end{array}$ & 4,635 & 3.00 & 0.70 \\
\hline & Respect & $\begin{array}{l}\text { Teachers respect those colleagues who are } \\
\text { experts at their craft }\end{array}$ & 4,660 & 3.17 & 0.68 \\
\hline & Meaning & $\begin{array}{l}\text { Teachers feel a strong sense of meaning and } \\
\text { purpose in our work }\end{array}$ & 4,617 & 3.08 & 0.68 \\
\hline
\end{tabular}


Torres, BulkLey, AND Kim, EDUCATIONAL ADMINistration QuARTERLY 56 (2020)

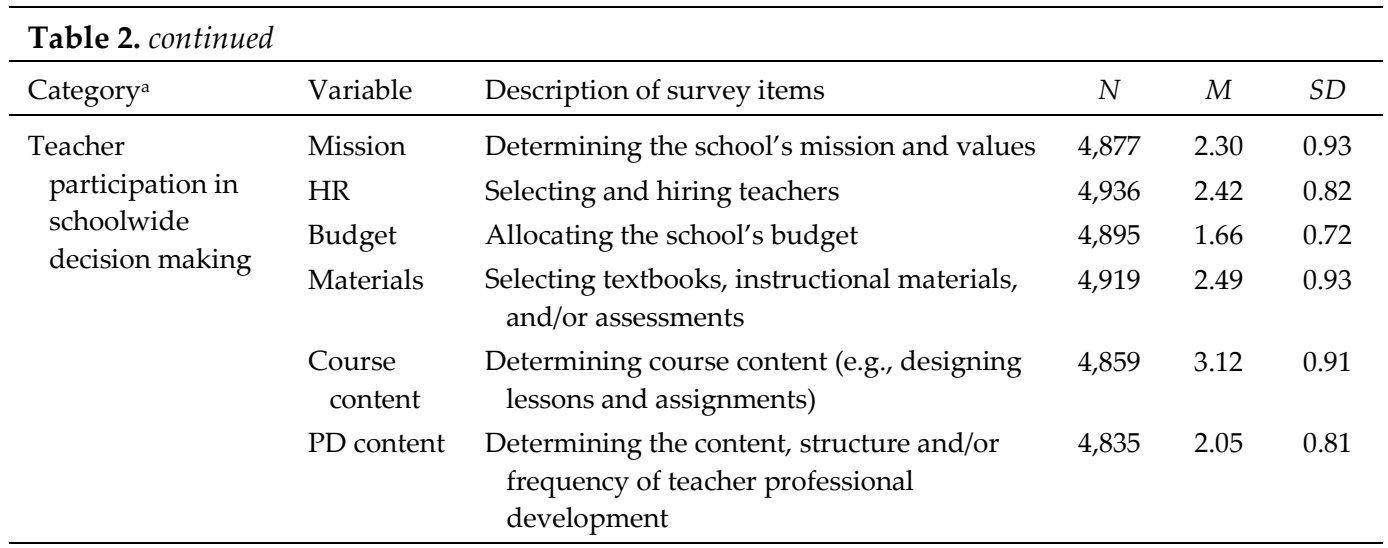

Note: We conducted an unweighted analysis to compare with the weighted analysis. The unweighted means and standard deviations are very similar. $\mathrm{HR}=$ human resource; $\mathrm{PD}=$ professional development.

aAll the answers were reported using a 4-point Likert-type scale (1 to 4).

${ }^{b}$ Answers were modified as binary (1: regular activity participating at least monthly basis, 0 : less frequent activity).

\section{Findings}

In this section, we first report the results of our qualitative case study ratings (see Figure 2). We then present short profiles describing schools that represent some of the variation and patterns that we observed and include examples of three distinct school types (innovation, CMO charter, and traditional public) to provide a general overview of how each school engaged in shared leadership for learning and how the specific school context influenced these orientations. These profiles allow us to demonstrate how the different components of shared leadership, as reflected in our conceptual framework, intersect in important ways. We then present comparative qualitative data that help us illustrate and explain differences and variations in ratings for case schools. Finally, we present descriptive results from our survey data that allow us to explore whether some of the patterns we found in case schools might extend more broadly across Denver's different school models.

Figure 2 shows that across models, ratings on shared leadership for instruction were relatively high (a 7 or 8), with only "Brown" (we used colors as pseudonyms for case study school names) receiving an overall rating of " 4. " By contrast, there was much more variation in terms of teacher influence on schoolwide decisions, with three charter schools receiving the lowest ratings (0-1), three innovation schools receiving the highest ratings (7-8), and two TPSs ranging somewhere in the middle (2 and 3; see Table 3 for ratings).

In the next sections, we explain these patterns and answer the research questions for this study. 
Table 3. Shared Leadership for Learning Ratings on Case Study Schools

\begin{tabular}{|c|c|c|c|c|c|c|c|c|c|c|c|}
\hline \multirow[b]{2}{*}{$\begin{array}{l}\text { School } \\
\text { name }\end{array}$} & \multirow[b]{2}{*}{$\begin{array}{l}\text { Governance } \\
\text { model }\end{array}$} & \multicolumn{5}{|c|}{ Shared instructional leadership } & \multicolumn{5}{|c|}{ Shared schoolwide decision making } \\
\hline & & $\begin{array}{l}\text { Teacher } \\
\text { leadership } \\
\text { responsi- } \\
\text { bilities }\end{array}$ & $\begin{array}{c}\text { Peer } \\
\text { support }\end{array}$ & $\begin{array}{l}\text { Principal } \\
\text { instruc- } \\
\text { tional } \\
\text { leadership }\end{array}$ & $\begin{array}{l}\text { Climate } \\
\text { of } \\
\text { collabo- } \\
\text { ration }\end{array}$ & Sum & $\begin{array}{l}\text { Vision/ } \\
\text { Goals }\end{array}$ & Personnel & Budget & Scheduling & Sum \\
\hline Blue & $\begin{array}{l}\text { Traditional } \\
\text { public }\end{array}$ & 2 & 2 & 2 & 1 & 7 & 0 & 0 & 1 & 1 & 2 \\
\hline Brown & $\begin{array}{l}\text { Traditional } \\
\text { public }\end{array}$ & 1 & 1 & 1 & 1 & 4 & 1 & 1 & 1 & 0 & 3 \\
\hline Cerise & Innovation & 2 & 2 & 2 & 2 & 8 & 2 & 2 & 2 & 2 & 8 \\
\hline Green & Innovation & 2 & 2 & 2 & 2 & 8 & 2 & 2 & 2 & 2 & 8 \\
\hline Khaki & $\begin{array}{l}\text { CMO } \\
\text { charter }\end{array}$ & 2 & 1 & 2 & 2 & 7 & 0 & 0 & 0 & 0 & 0 \\
\hline Purple & $\begin{array}{l}\text { Stand-alone } \\
\text { charter }\end{array}$ & 2 & 2 & 2 & 2 & 8 & 0 & 0 & 0 & 1 & 1 \\
\hline Teal & $\begin{array}{l}\text { CMO } \\
\text { charter }\end{array}$ & 1 & 2 & 2 & 2 & 7 & 0 & 1 & 0 & 0 & 1 \\
\hline Viridian & Innovation & 2 & 2 & 2 & 2 & 8 & 2 & 2 & 2 & 1 & 7 \\
\hline
\end{tabular}

Note: Red $=$ accredited on probation; Orange $=$ accredited on priority watch; Yellow = accredited on watch; Green = meets expectations; Blue $=$ distinguished $; \mathrm{CMO}=$ charter management organization

\section{Example/Illustrative Case Profiles}

Green: Innovation school

Green is one of Denver's "innovation" schools and is part of the LLN. At Green, teachers described various structures for collaboration and professional learning, including data team meetings and teacher-led professional development that one participant described as "a committee comprises teachers from all four schools to allow for cohorts to focus on different problems of practice." Teacher leaders noted that having the central structure of the LLN allowed for meaningful collaboration across the school sites, and also noted that this structure acted as a "lab" for innovation that DPS could learn from. At the same time, school leaders at Green explained that they could opt into district initiatives or supports and, as was the case with all innovation schools in our sample, they did so with DPS' teacher leader model.

Consistent with the vision of the LLN, shared schoolwide decision making extended to many different kinds of leadership decisions at Green, illustrating a theme across the innovation schools in our sample. Teachers and teacher leaders alike described "democratic processes" aimed at giving them input into decisions about scheduling, budget, the vision and direction of the school, and teacher hiring. For example, one teacher explained, "There's a group of teachers that creates a schedule. They create schedule offerings and then teachers get to vote on these."

\section{Teal: Charter management organization school}

Teal, a CMO-managed elementary charter school that served predominantly low-income students of color, was a place with consistent and high expectations of both staff and students. The vision of the $\mathrm{CMO}$ dominated the daily practices within the school, driven by 
confidence in the CMO's model and a focus on implementing that model with fidelity. This explained a theme across our CMO case sites, where there was relatively little autonomy around the "big picture" decisions about the school.

Central to the Teal CMO's model was a strong focus on shared instructional leadership, with multiple formalized ways in which both administrators and teaching staff work together around instructional improvement. Included in this were opportunities for teachers to have formal administrative instructional support roles. Collaboration and principal coordination were described as "strong." For example, one teacher explained,

The other [grade level] teacher and I often meet several times throughout the day just to check in real quick and see what went well in the lesson and what didn't, what we need to target and hit. I feel like the instructional coaches are really open ... I feel like the collaboration is immediate and quick.

Multiple participants discussed specific instructional challenges that they or others had faced and the ways in which teachers and leaders had worked together to address those challenges.

While shared instructional leadership was central to Teal's approach, it was done within a highly structured CMO model that meant little autonomy or influence for either school leaders or teachers around most school-level issues including the overall vision for the school, budget, and scheduling. This lack of autonomy was clear from the outset to staff members and one leader questioned the assumption that autonomy is inherently helpful to schools, arguing:

When you give those levels [in schools, such as teachers or leaders] autonomy and you have not done the prep work to get people ready for it, what, does it actually lead to a change in outcome in performance or is the autonomy leveraged to make change?

While the norms of little autonomy were clear, participants noted that there was room to make a case for changes, so long as that case included a clear rationale and ties to achievement data.

Brown: Traditional public school

Brown was a diverse and relatively small elementary school, in which the staff worked hard to improve negative perceptions in the community tied to poor performance, decreasing enrollments, and some challenges around student behavior. After a series of short-term principals and high levels of staff turnover, the principal (in his third year at the time of our visit) had sought to build stability in staffing while also rethinking the direction of the school. The year after this study, the school was set to adopt a new vision and program that had shown success elsewhere, and that shift was a regular point of conversation. Staff described the principal as open and willing to listen, and those working in the school as having an increasing sense of satisfaction since he became the principal. It was also clear, however, that the principal was the primary decision maker in the school. While there were 
some formal structures for schoolwide decision making such as hiring committees, two teacher leaders agreed that the principal was "clear about who he wants for positions."

Relative to other schools in our study, we saw only modest evidence of shared instructional leadership in Brown, other TPSs, and our stand-alone charter school. This reflected a theme of dependence on the individual capacities and preferences of the principal rather than the influence of a larger structural "model" as we saw in the cases of innovation and CMO schools. Specifically, the principal was described as "putting faith" in the staff and therefore not "micromanaging" their instruction and teachers did not describe either formal structures or informal practices involving collaborative work with their colleagues or school culture around instructional improvement. For those working in the school, this was not identified as a problem but rather as a reflection of confidence and a measure of the autonomy provided to teachers. As one teacher described, "as long as you're doing your job and meeting expectations ... you're left alone and it's an open-door policy to go see the principal whenever there's any issues or whenever you wanted to chat." One teacher described team teaching as a way in which they supported each other to improve, but this varied by classroom. Another teacher explained that the principal wanted more collaboration to happen, and others pointed to professional development offered by DPS (which varied in terms of how well teachers felt it met their needs and those of the school) as the primary source for teacher learning.

\section{Shared Instructional Leadership: Cross-Case Comparisons}

In this section, we explore the subcomponents of shared instructional leadership, drawing on the school profiles and our cases to illuminate the ways in which these subcomponents varied depending on school governance types.

\section{Teachers with leadership responsibilities}

Several schools described formal teacher leadership structures (consistent with the district initiative). For example, formal Teacher Leaders at the innovation schools Viridian and Cerise described how their positions involved teaching part-time and then having "caseloads" of teachers who they both supported through regular meeting and with whom they conducted formal evaluations. Both Viridian and Cerise chose to formally adopt the district's teacher leadership initative. While Teal (CMO) and Purple (stand-alone) also had supports for instructional improvement they came from formal administrative instructional leaders, not teacher leaders.

Peer support for instructional improvement

Many of the schools we visited actively engaged teachers in supporting their colleagues. One mechanism for this work was teacher-led professional development. For example, teachers at Green, Viridian, and Cerise (all of which were innovation schools) discussed a school culture in which teachers were viewed as experts and charged with leading formal professional development as well as broader learning. At Green and Cerise, this included teachers who participated in an LLN-wide teacher council that helped identify and offer professional development to all the LLN schools. At Purple, teacher evaluation was used as an opportunity for teachers to support one another, as "veteran" staff members could 
choose to participate in peer coaching and evaluation rather than traditional evaluations by leaders. Finally, the formal teacher leaders described above played a critical role in coaching their colleagues on an ongoing basis in Cerise and other schools. In contrast to this picture of teachers actively engaged with one another, teachers at Brown (see earlier section) described a context in which they were largely left alone rather than expected to work together, which did not resonate with the idea of promoting collective capacity among teachers.

\section{Principal instructional leadership and coordination/support}

While we saw variation in some aspects of instructional leadership, we found that all of the schools that we visited had principals who played at least some active and intentional role around directly supporting individual teachers in improving instruction and structuring teacher influences on instruction. However, the specific nature of their approaches differed in ways consistent with the overall tenor of the school. For example, in highly structured Teal and Khaki, the roles of teachers and the ways in which they worked in teams around data use and overall instructional practices were largely determined by the principal and $\mathrm{CMO}$ leaders. In contrast, consistent with a less top-down approach, leaders in Purple supported teacher learning through expectations about the development of teacher-led groups. One teacher explained, "we are allowed to opt into working groups that we design. Then, within those working groups, we hold each other accountable."

\section{Positive climate of teacher collaboration}

In six of the schools, we saw evidence of a school culture that valued collaborative conversations between teachers, indicative of a culture of trust and openness. Many of these schools described structured data team meetings, peer coaching, or horizontal and vertical curricular planning as well as a culture in which teachers were open to sharing their difficulties and ideas to improve instructional practices. A teacher in Green said, "[the math team] can accomplish the most and align the best, given [we're] are all math teachers collaborating together." On the other hand, our evidence suggested that two schools operated with more of a traditional "closed door" culture. At Brown, as described above, the principal's "hands-off" approach was appreciated by teachers but was not consistent with a school culture that emphasized conversation and collaboration around instruction.

\section{Schoolwide Decision Making: Cross-Case Comparisons}

Vision and goals

While more difficult to "see" in schools that were not undergoing major changes in mission and vision, we were able to assess teachers' perceptions of input in these areas as well as concrete structures and practices that shaped these perceptions. For example, teachers in the LLN schools described an annual process for looking at the school vision in conjunction with the budget and the school improvement plan to ask, as one teacher leader at Green put it: "how do we make sure this is first and foremost in our minds? What do we need to do as a school to build it in?" A teacher leader at Cerise described this process as including input from all teachers after work was done by a committee of "team leaders": 
TOrRes, BulKLey, AND Kim, EDUCATIONAL ADMINistration QuARTERLY 56 (2020)

Principal and assistant principal have a vision. They come to the senior team leaders. That vision is shared with the team leaders and we say "hey, I agree, I don't agree, can we add this or not?" and then we go to the teachers and say, "hey, this is what we have been working on, are we agreeing on this?" It's kind of like every beginning of the year, we set up that vision for the school.

Viridian's (innovation) principal solicited input from all teachers and then had volunteers work on the details. One teacher leader said,

[We're asked]: what level of input do you want to have? Do you want to be really involved with writing it? Do you want to have it e-mailed to you to check certain parts that might be relevant? Do you want to just not have very much input?

Each of the innovation schools developed processes to collect input from all teachers and to actively and annually involve them in reexamining and crafting mission and vision.

By contrast, the $\mathrm{CMO}$ and stand-alone charters were working within preestablished visions. In these organizations, mission and vision were defined not by school leaders but by the charter organization or founder. Despite teachers and leaders saying they did not have input into the established model, this was framed as good for efficiency, allowing leaders and teachers to focus on implementation and instruction. When asked whether they had autonomy around curriculum and mission the leader of Khaki said, "No. And I'm OK with that." By contrast, school leaders in the TPSs in our sample were attending to issues of mission and vision, but in what some teachers described as a "top-down" fashion. Teacher leaders at Blue felt that most teachers were fine with the principal basing the mission off their "personal experience" but one of them said: "I think it would be nice to have more input about really thinking about how to reach the vision that's being created instead of just being told."

\section{Scheduling}

In most schools in our study, decisions about scheduling were made largely by the school leader or other organizational leadership. For example, big decisions in a number of areas were made at the CMO central office level so that school leaders and teachers could focus intensively on instruction. Again, this mentality was viewed as creating efficiencies; as the director of Teal explained, "I do not want you scratching your head on our school finances. I do not want you scratching your head on an issue tied to food services or transportation."

Green had a much more democratic approach to scheduling, with teacher teams crafting multiple versions and holding a vote over the preferred master schedule. One teacher explained,

We had a meeting all about the schedule and different options we could have, and we were able to say, I don't want this time period for specials, but anything else could work - like, [the committee has] taken a lot of input on a lot of things. 
Other schools aspired to this but fell short. For example, Blue had a school leadership team working on scheduling. This theoretically gave teachers input on, as one teacher explained, "the schedule, certain dates like parents teacher conference [and professional development] ... they're less academic, more operational."

However, two teacher leaders involved in this leadership team described several ways in which they did not feel heard around various decisions, including scheduling and hiring. For example, one explained, "I noticed that all the decisions that we had made seemed to have been changed." This was a notable change for these teacher leaders, since Blue's principal was new and the old principal had a very different orientation, as one explained, "I had my hand in a lot of things last year ... I felt like I was a liaison." Both teacher leaders were disappointed about losing voice and considered leaving, as the dynamic with the new leader made them feel devalued.

\section{Hiring and budget}

The dynamic at Blue also extended to issues of teacher hiring. Whereas teacher leaders said they used to have input on decisions about who was hired, a personnel committee remained in place but one teacher on it explained, "I don't necessarily feel my voice is heard." With the exception of Teal, whose central office recruiter asked informally for teachers' opinions of teacher candidates, hiring in charter schools was typically done by the principal in conjunction with other organizational leaders (e.g., central office personnel).

As in other areas of schoolwide decision making, the innovation schools each gave teachers substantial input in the hiring process. One teacher at Cerise explained that teachers and parents served on hiring committees, though principals had the final say. A Viridian teacher also noted: "We're invited to the interviews. I have one tomorrow for my potentially new partner."

These same patterns were consistent with decisions about the budget. Leaders in the TPSs explained that DPS was allowing principals more and more autonomy to make decisions, as the leader at Blue explained,

I think with also school-based budgeting in Denver and even more so with more flexibilities as far as curricular choices, assessment choices, more-I guess more onus on principals to choose their people and govern their time within their school, and even before and after the school day. That has been enormous.

In the case of budget, leaders at Blue and Brown collaborated with school leadership teams (comprised in part by teachers) to make these decisions. By contrast and similar to processes for examing vision and goals, all teachers in innovation schools were asked to review decisions and offer their thoughts, as a teacher at Green explained,

When the budget comes due, we look at what are the needs of the whole building, and we prioritize [based on students' needs]. . . . Teachers are able to see what the budget is going to be. We do have input. 


\section{Influence of School Model and Governance Contexts}

Whether teachers shared in decision making depended a great deal on their organizational context and the vision of the organizational structure that schools were embedded in. Unlike charter schools in our sample with more top-down models, innovation schools took a bottom-up approach consistent with the LLN vision. Thus, innovation schools in our sample had structures in place for teachers to regularly examine and give input on various decisions (including Viridian - not part of the LLN, but it adopted many of the strategies of LLN schools).

In terms of the larger governance context, we found that Denver's accountability system affected the level of risk and willingness to share leadership decisions among some leaders. A teacher leader at Viridian explained that increased pressure for performance had the potential to constrain principals' ability/autonomy to make their own decisions:

I wonder if we wouldn't have more district pressure if we weren't performing well. The year or two that we were Yellow, there was suddenly all of this pressure from the district and micromanaging and, "Oh, we're going to have to look at your innovation plan." Even when it was based on 1-year scores, we were Yellow. Now we're Green again.

In the case of Blue's new principal, teacher leaders felt he was experiencing intense pressure that influenced his desire to make decisions "behind closed doors":

I'm not sure he's managing this year. I think that he was super awesome in the beginning of the year. Then, when testing time rolls around, it gets really stressful, and hiring and evaluation time, and all of that. I feel like that's when everything shifted and he became different and making decisions behind closed doors. I think it's fear of failing and his ego of I want to have a good school.

In this sense, teacher leaders at Viridian and Blue pointed out that there were both structural (e.g., the district) and individual leader responses to accountability that could restrict the extent to which teachers and leaders could or were willing to make shared decisions. Even though the district granted autonomy at the school level, the pressures from the accountability measures appeared to curtail principals' comfort with sharing school-level autonomy with teachers.

Additionally, accountability influenced one principal's decision to significantly shift a school's mission and vision. When asked about accountability and the switch to a new model, Brown's principal said, "I think that's one reason why we are moving to [that model]. I think kids just do better." A teacher leader at Brown added, "[The principal] went on a trip last year to visit [new model] schools. They have, I think on an average, better test scores." Teacher leaders at Brown noted that the principal made this decision without formally soliciting their input. 


\section{Survey Results}

We analyzed data from teacher surveys to compare the different school contexts and found that survey data generally aligned (with some exceptions) with our qualitative results: While teachers' responses from CMO, traditional, and innovation schools largely reflect our qualitative findings, the lowest scores from stand-alone charter teachers did not align with what we found at Purple (stand-alone charter), which showed high ratings in terms of shared instructional leadership. Stand-alone charter schools may vary in a range of how leaders enact shared leadership for learning because they are not influenced by any umbrella institutions but by individual leaders and internal factors. Therefore, we cannot say that Purple is typical of stand-alone schools. As we point out in the next section, there were some exceptions: for example, stand-alones had among the highest ratings of trust and collaboration, and CMO teachers perceived high levels of influence in decisions about instructional content and materials.

Peer support for instructional improvement

Looking at Table 2, over half of the teachers in our overall sample on average reported that they participated in four activities on at least monthly basis (or more frequently): meeting with colleagues to improve their practice $(74 \%)$, meeting with other school staff to discuss needs of individual students $(68 \%)$, meeting with colleagues to analyze student achievement $(65 \%)$, and meeting with an instructional coach (58\%). Our survey analysis supports high scores on shared instructional leadership in our case study sites (see Figure 2) and provides additional evidence about how teachers may focus differently (on average) on certain activities depending on their school models.

Table 4 shows that more than $70 \%$ of teachers at both traditional public and innovation schools reported they met with other teachers to analyze student data and to improve their practice. While teachers at charter schools (both CMO and stand-alone) reported high rates of meeting with other teachers to improve practice monthly or weekly $(73 \%, 63 \%$, respectively), less than half of their teachers ( $46 \%$ for each charter school type) reported they met with other teachers to discuss student data monthly or weekly. Instead, teachers at CMO charters reported the highest rate in meeting with an instructional coach $(82 \%)$. This result supports our qualitative findings that innovation schools tended to be more driven by teacher teams and teacher leaders, whereas CMO charters leaned more on formal administrative coaches or instructional leaders. 


\begin{tabular}{|c|c|c|c|c|c|c|c|c|c|c|c|}
\hline \multirow[b]{2}{*}{ Category } & \multirow[b]{2}{*}{ Variable } & \multicolumn{2}{|c|}{ TPS } & \multicolumn{2}{|c|}{ Innovation } & \multicolumn{2}{|c|}{$\mathrm{CMO}$} & \multicolumn{2}{|c|}{ Stand-alone } & \multirow[b]{2}{*}{$F$} & \multirow{2}{*}{$\begin{array}{l}\text { Signifi- } \\
\text { cance }\end{array}$} \\
\hline & & $N$ & Mean & $N$ & Mean & $N$ & Mean & $N$ & Mean & & \\
\hline \multirow{4}{*}{$\begin{array}{l}\text { Peer support for } \\
\text { instructional } \\
\text { improvement }\end{array}$} & Analyze data & 2,565 & 0.71 & 862 & 0.76 & 775 & 0.46 & 439 & 0.46 & 98.10 & $* * *$ \\
\hline & Practice & 2,561 & 0.76 & 880 & 0.76 & 775 & 0.73 & 439 & 0.63 & 10.73 & $* * *$ \\
\hline & Met coach & 2,489 & 0.54 & 853 & 0.67 & 765 & 0.82 & 433 & 0.26 & 145.86 & $* * *$ \\
\hline & Student needs & 2,589 & 0.65 & 856 & 0.73 & 775 & 0.79 & 433 & 0.55 & 32.82 & $* * *$ \\
\hline \multirow{6}{*}{$\begin{array}{l}\text { Principal instructional } \\
\text { leadership and } \\
\text { coordination/support }\end{array}$} & Standards & 2,475 & 3.25 & 844 & 3.25 & 756 & 3.33 & 377 & 2.97 & 20.86 & $* * *$ \\
\hline & Resource & 2,446 & 2.92 & 834 & 2.95 & 744 & 2.96 & 368 & 2.67 & 11.84 & $* * *$ \\
\hline & PD & 2,431 & 2.90 & 874 & 2.89 & 765 & 2.90 & 384 & 2.70 & 7.51 & $* * *$ \\
\hline & Quality & 2,434 & 2.84 & 844 & 2.79 & 752 & 2.88 & 383 & 2.43 & 26.37 & $* * *$ \\
\hline & Coaching & 2,353 & 2.63 & 820 & 2.68 & 733 & 2.78 & 378 & 2.29 & 25.24 & $* * *$ \\
\hline & Accountable & 2,352 & 3.09 & 858 & 3.05 & 745 & 3.20 & 386 & 2.66 & 43.73 & $* * *$ \\
\hline \multirow{7}{*}{$\begin{array}{l}\text { School climate of } \\
\text { collaboration }\end{array}$} & Share & 2,580 & 3.27 & 874 & 3.19 & 775 & 3.42 & 430 & 3.14 & 23.86 & $* * *$ \\
\hline & Advice & 2,580 & 3.23 & 874 & 3.24 & 775 & 3.37 & 424 & 3.27 & 10.73 & $* * *$ \\
\hline & Trust & 2,591 & 3.01 & 860 & 3.12 & 775 & 3.32 & 430 & 3.16 & 44.81 & $* * *$ \\
\hline & Discuss & 2,578 & 2.91 & 868 & 3.04 & 775 & 3.29 & 430 & 3.25 & 68.54 & $* * *$ \\
\hline & Lead & 2,591 & 2.84 & 860 & 3.03 & 765 & 3.36 & 419 & 3.24 & 141.73 & $* * *$ \\
\hline & Respect & 2,591 & 3.04 & 874 & 3.21 & 775 & 3.49 & 419 & 3.29 & 100.41 & $* * *$ \\
\hline & Meaning & 2,556 & 2.97 & 866 & 3.11 & 775 & 3.38 & 419 & 3.13 & 78.20 & $* * *$ \\
\hline \multirow{6}{*}{$\begin{array}{l}\text { Teacher participation } \\
\text { in schoolwide } \\
\text { decision making }\end{array}$} & Mission & 2,735 & 2.28 & 911 & 2.73 & 814 & 2.06 & 417 & 2.00 & 102.52 & $* * *$ \\
\hline & HR & 2,759 & 2.51 & 914 & 2.63 & 846 & 2.26 & 417 & 1.74 & 147.37 & $* * *$ \\
\hline & Budget & 2,730 & 1.72 & 902 & 1.84 & 846 & 1.47 & 417 & 1.27 & 88.07 & $* * *$ \\
\hline & Materials & 2,759 & 2.33 & 908 & 2.68 & 835 & 2.79 & 417 & 2.47 & 71.13 & $* * *$ \\
\hline & Course content & 2,713 & 3.03 & 898 & 3.32 & 846 & 3.27 & 402 & 2.91 & 38.45 & $* * *$ \\
\hline & PD content & 2,692 & 2.02 & 908 & 2.20 & 825 & 2.07 & 411 & 1.83 & 22.34 & $* * *$ \\
\hline
\end{tabular}

Note: All the $F$ values resulting from analysis without weights showed significance at the a $=.05$ level except the following four items: Share $(F=1.47, p=.02)$, Advice $(F=1.40, p=.24)$, Practice $(F=2.50, p=.06)$, and PD $(F=1.95, p=.12)$. ANOVA = analysis of variance; TPS = traditional public school; CMO = charter management organization; $\mathrm{HR}=$ human resource; $\mathrm{PD}=$ professional development. ${ }^{*} p<.05 .{ }^{* *} p<.01 .{ }^{* * *} p<.001$.

\section{Principals' instructional leadership and coordination/support}

Overall, ratings between traditional, innovation, and CMO schools were fairly similar, with $\mathrm{CMO}$ teachers indicating slightly higher ratings of principals and stand-alone charter teachers, on average, rating principals slightly lower than the other three models (see Table 2). The post hoc tests also showed that teachers' responses from stand-alone charters were significantly lower than each of the three school models for all the items regarding principal instructional leadership.

\section{School climate of collaboration}

The third category in Tables 2 and 4 shows teachers' perceptions of their school climate in terms of collaboration. On average, teachers in all school types reported relatively high scores (most scores are above 3) which suggests that many schools in Denver may have shared norms around teacher trust and collaboration across school models. Table 4 shows that scores from TPSs were relatively lower than the other three school models. For example, teachers in TPSs rated a 2.84 regarding respect for other teacher leaders, while innovation, $\mathrm{CMO}$, and stand-alone charter schools showed ratings above $3(3.03,3.36,3.24$, respectively). CMO and stand-alone charter schools showed higher scores than innovation and TPSs. 


\section{Schoolwide decision making}

Innovation schools had the highest average scores in most areas compared with the other three school types except selecting instructional materials (see Table 4). Considering ratings of influence on school mission and values, the biggest gap was between innovation schools and the other three school models. This mirrors what we found in our case study data, as conversations and opportunities for input from teachers around mission and values were somewhat more robust compared with charter and TPSs.

Finally, our qualitative data highlighted how teacher commmittees, teacher leaders, and instructional leadership teams typically form the basis for allowing teachers to have input into schoolwide decision making. We interpret the relatively low average scores in this category as a reflection that teachers not formally involved in these structures likely provided lower ratings.

\section{Discussion}

Offering different school contexts from which parents and students can choose while holding those schools accountable for high performance is theoretically central to the portfolio approach. Yet we know little about how or why school context or governance affects shared influence on instruction and decision making despite their relationship to teacher commitment and student achievement (e.g., Ingersoll et al., 2018; Louis, Leithwood, et al., 2010).

Overall, we found that participants from Denver's innovation schools had among the highest perceptions in both shared instructional leadership and schoolwide decision making. This finding was consistent in survey data and in our innovation case study schools. Both sets of data found that CMOs ranked high in terms of shared instructional leadership and were among the lowest in terms of schoolwide decision making in the areas of mission, budget, and hiring. Traditional and stand-alone charter schools ranked lower in the survey and case data, though stand-alone schools in the survey data had the lowest levels in both aspects with the exception of collaboration and trust. The lower average scores we saw in stand-alone charter schools might be related to limited resources or time since stand-alone leaders are often charged with coordinating all aspects of the school (Torres, Bulkley, \& McCotter, 2018), whereas other school models rely on resources (e.g., HR, operations) through existing structures and networks provided by the district and/or CMO.

The presence of a centralized structure and the vision of that structure in the innovation (LLN-e.g., vision of teacher empowerment), DPS, and CMO contexts also had a strong influence on shared leadership for learning. DPS's formal teacher leader initiative was adopted by TPSs throughout Denver and the innovation schools in our sample all chose to adopt it. In this sense, the district as portfolio manager actively provided structures to build capacity for shared instructional leadership in TPSs and innovation schools. This approach in Denver may be in contrast to portfolio managers in cities like New Orleans that largely take a hands-off approach when it comes to capacity building efforts (Torres, Bulklry, Hashim, et al, 2018). The portfolio manager also indirectly facilitated shared decision making by providing LLN schools with the autonomy to create and actualize a new vision centered on teacher empowerment. Leaders in TPS and CMO schools also felt supported by their central offices. For example, much of the capacity building at Blue seemed 
to come from the district, which assisted with marketing, managing utilities and services, providing support for developing the school's mission, providing the principal with an executive coach, network instructional coaches, and an Instructional Superintendent whom the principal characterized as a "great thought partner."

Despite the presence of the central office, DPS did not mandate a particular approach or (other than the SPF) provide philosophical or pedagogical parameters around practice in the ways that the LLN and CMOs did. Thus, the ways in which shared leadership for learning in TPSs were enacted depended on the individual leader, which was similar to the stand-alone charter school in our cases. The autonomy for each individual leader to engage in shared decision making may help explain the variation we saw for TPS in our data.

Our findings suggest that while the school leader is indeed pivotal to sharing influence (e.g., Hallinger \& Heck, 1996; Johnson et al., 2014), equally important is the broader organizational vision which can either enhance or limit school leaders' ability to involve teachers. For instance, CMOs that had more fixed approaches to decision making and instruction had strong perceived coherence in terms of the instructional focus, but this also resulted in little shared decision making for either school-based leaders or teachers because the CMOs' "model" was already in place. CMO leaders and teachers noted the tradeoff between efficiency and having input in their school models. Compared with stand-alone contexts, CMOs provide support and decision making around various leadership activities such as operations, HR, budget, and overarching instructional philosophy which affords them more time to focus on instruction (Torres, Bulkley, \& McCotter, 2018; Jacobson et al., 2009; Lake \& Hill, 2009). By contrast, the vision of the LLN focused on teacher empowerment across schools with distinct missions, and this vision enabled structures for shared decision making that teachers generally appreciated.

In terms of the impact of the larger PMM governance context, accountability policies such as the SPF and the teacher leadership initiative in Denver had a notable influence on shared leadership for learning. Unsurprisingly, the SPF put greater pressure on lower performing schools and leaders. Leaders in low-performing schools had mixed responses to accountability pressure with some opting for more of a top-down approach to decision making and one leader at a TPS noting that it influenced their decision to shift in the overall vision and mission of the school, though teachers were not necessarily involved in this decision. Our findings highlight how a PMM, in which pressure from performance-based accountability is central, could discourage leaders from promoting shared leadership for learning.

\section{Implications for Research, Policy, and Practice}

Although research shows a strong connection between shared influence and student achievement, our qualitative approach allowed us to understand whether and why sharing influence may or may not be beneficial for achievement. For example, given the higher than average outcomes of CMOs (McEachin et al., 2016), there is a case to be made that certain decisions can or should be made without significant teacher input. However, CMOs' efficiencies may also come at a cost. Research on charter schools and professional autonomy suggest that some CMOs struggle to find teachers who are the right fit for their 
narrowly defined or "prescriptive" models (Torres, 2016). As newer teachers grow in their expertise and educational philosophy in ways inconsistent with their organizational model, they may come to disagree with the model or search for professional growth outside of it (Torres, 2014). Both of these conditions can make it difficult to hire and retain teachers in CMOs (Torres, 2016). CMO leaders should therefore solicit teacher feedback and meaningfully involve teachers in decisions.

Other research on shared decision making describes not just the benefits but also the potential challenges: time demands on teachers, building familiarity with policies, and in some cases, engaging in conflict with colleagues or leaders over decisions (Weiss et al., 1992). Leaders and teachers should weigh the potential benefits (e.g., empowerment, commitment, an improved school climate) with these potential challenges that are related to school contexts. Leaders should thoughtfully structure opportunities for shared decision making by assessing teacher readiness, forming volunteer committees, and allowing all teachers to voice their opinion on major decisions in some fashion.

While most studies on portfolio management focus on describing PMMs and measuring how they are related to achievement outcomes as we described in our literature review, we add to an emerging foundation of studies that explain how and why these governance systems are shaping school practices. Some believe that providing substantial school-based autonomy, which may come with a decreased reliance on centralized or coordinated support structures and more reliance on external support providers, can be ideal for many schools (Lake \& Hill, 2009). For instance, Gigliotti (2019) notes that the autonomy of innovation schools in Denver may be responsible for the positive outcomes observed, yet our study suggests that innovation schools opting into some of the capacity supports created by DPS (such as the teacher leader initiative) could be helpful in terms of both efficiency and capacity building.

In this sense, PMMs should not neglect the capacity-building function of the central office and exclusively delegate school-level supports to external providers. Some districtlevel centralization can enable support for individual school leaders and provide them with normative directions and multiple resources in promoting shared instructional leadership or shared decision making and may help minimize the school-by-school variation in these areas. At the same time, networks designed to replicate school models that are successful at meeting academic goals such as CMOs may also limit autonomy or the potential for innovation and encourage the proliferation of similar schools rather than variation in the kinds of school models available to families in a PMM. These tradeoffs should also be considered in the context of the larger goals of the system or district.

Though outside the scope of our mixed-method study, more research should examine how, why, and under what conditions shared leadership for learning is linked to different outcomes (e.g., achievement, commitment, climate, etc.). One limitation to our work is that we examined perceived quality of shared leadership for learning, and future research linking practices to outcomes can help answer questions about actual quality of these structures.

In conclusion, Denver's PMM illustrates how autonomy can coexist in thoughtful ways with the presence of coordinated, centralized supports in ways that empower teachers and leaders to share leadership over instruction and decision making. 
Declaration of Conflicting Interests - The authors declare no potential conflicts of interest with respect to the research, authorship, and/or publication of this article.

Funding - The authors disclose receipt of the following financial support for the research, authorship, and/or publication of this article: Financial support for the research through a Lyle Spencer Grant from the Spencer Foundation.

\section{Note}

1. Our post hoc test analysis results are available following the references.

\section{References}

Allensworth, E., \& Hart, H. (2018). How do principals influence student achievement? University of Chicago Consortium on School Research.

Augustine, C. H., Gonzalez, G., Ikemoto, G. S., Russell, J., Zellman, G. L., Constant, L., Armstrong, J., \& Dembosky, J. W. (2009). Improving school leadership: The promise of cohesive leadership systems. Rand Corporation.

Backes, B., \& Hansen, M. (2018, January). Reaching further and learning more? Evaluating public impact's opportunity culture initiative (CALDER Working Paper No. 181). https://caldercenter.org/ publications/reaching-further-and-learning-more-evaluating-public-impacts-opportunity-culture

Bernd, M. (1992). Shared decision making requires effective instructional leadership. NASSP Bulletin, 76(540), 64-69. https://doi.org/10.1177/019263659207654011

Bickmore, D. L., \& Dowell, M.-M. S. (2011). Concerns, use of time, and the intersections of leadership: Case study of two charter school principals. Research in the Schools, 18(1), 44-61.

Bogler, R., \& Nir, A. E. (2012). The importance of teachers' perceived organizational support to job satisfaction: What's empowerment got to do with it? Journal of Educational Administration, 50(3), 287-306. https://doi. org/10.1108/09578231211223310

Buerger, C., \& Harris, D. (2015). How can decentralized systems solve system-level problems? An analysis of market-driven New Orleans school reforms. American Behavioral Scientist, 59(10), 1246-1262. https://doi.org/10.1177/0002764215591182

Bulkley, K. (2005). Losing voice? Educational management organizations and charter schools' educational programs. Education and Urban Society, 37(2), 204-234.

Bulkley, K. E., Henig, J. R., \& Levin, H. M. (2010). Between Public and Private: Politics, Governance, and the New Portfolio Models for Urban School Reform. Harvard Education Press.

Bush-Mecanas, S., \& Marsh, J. A. (2018). The DIVE approach: Using case-ordered meta-matrices and theory-based data displays to analyze multiple case study data. In C. Lochmiller (Ed.), Complementary research methods for educational leadership and policy studies (pp. 33-56). Springer.

Carpenter, D. M., \& Peak, C. (2013). Leading charters: How charter school administrators define their roles and their ability to lead. Management in Education, 27(4), 150-158. https://doi.org/10.1177/ 0892020613487919

Cooper, K. S., Stanulis, R. N., Brondyk, S. K., Hamilton, E. R., Macaluso, M., \& Meier, J. A. (2016). The teacher leadership process: Attempting change within embedded systems. Journal of Educational Change, 17(1), 85-113. https://doi. org/10.1007/s10833-015-9262-4 
TOrRes, BulKLey, AND Kim, EDUCATIONAL ADMINistration QuARTERLY 56 (2020)

Cravens, X. C., Goldring, E., \& Penaloza, R. (2012). Leadership practice in the context of U.S. school choice reform. Leadership and Policy in Schools, 11(4), 452-476. https://doi.org/10.1080/15700763 .2012.700989

Creswell, J. W., \& Clark, V. L. P. (2007). Designing and conducting mixed methods research. Sage.

Denice, P., \& Gross, B. (2016). Choice, preferences, and constraints: Evidence from public school applications in Denver. Sociology of Education, 89(4), 300-320. https://doi.org/10.1177/0038040716664395

DiMartino, C. (2014). Navigating public-private partnerships: Introducing the continuum of control. American Journal of Education, 120(2), 257-282. https://doi.org/10.1086/674375

Furgeson, J., Gill, B., Haimson, J., Killewald, A., McCullough, M., Nichols-Barrer, I., Teh, B-r., VerbitskySavitz, N., Bowen, M., Demeritt, A., Hill, P., \& Lake, R. (2012). Charter-school management organizations: Diverse strategies and diverse student impacts. https://files.eric.ed.gov/fulltext/ED528536.pdf

Gallucci, C., \& Swanson, J. (2006). Aiming high: Leadership for district-wide instructional improvement. Center for the Study of Teaching and Policy (CTP).

Gigliotti, P. (2019). Leveraging managerial autonomy to turn around low-performing schools: Evidence from the innovation schools program in Denver public schools. Advance online publication. http://dx.doi .org/10.2139/ssrn.3419472

Gold, E., Christman, J. B., \& Herold, B. (2007). Blurring the boundaries: A case study of private sector involvement in Philadelphia public schools. American Journal of Education, 113(2), 181-212.

Grissom, J. A., Loeb, S., \& Master, B. (2013). Effective instructional time use for school leaders: Longitudinal evidence from observations of principals. Educational Researcher, 42(8), 433-444. https://doi .org/10.3102/0013189X13510020

Gronn, P. (2000). Distributed properties: A new architecture for leadership. Educational Management Administration E Leadership, 28(3), 317-338. https://doi.org/10.1177/0263211X000283006

Hallam, P. R., Smith, H. R., Hite, J. M., Hite, S. J., \& Wilcox, B. R. (2015). Trust and collaboration in PLC teams: Teacher relationships, principal support, and collaborative benefits. NASSP Bulletin, 99(3), 193-216. https://doi.org/10.1177/0192636515602330

Hallinger, P. (2011). Leadership for learning: Lessons from 40 years of empirical research. Journal of Educational Administration, 49(2), 125-142. https://doi.org/10.1108/09578231111116699

Hallinger, P. (2018). Bringing context out of the shadows of leadership. Educational Management Administration E Leadership, 46(1), 5-24. https://doi.org/10.1177/1741143216670652

Hallinger, P., \& Heck, R. H. (1996). Reassessing the principal's role in school effectiveness: A review of empirical research, 1980-1995. Educational Administration Quarterly, 32(1), 5-44. https://doi.org/10 $.1177 / 0013161$ X96032001002

Harris, A., Leithwood, K., Day, C., Sammons, P., \& Hopkins, D. (2007). Distributed leadership and organizational change: Reviewing the evidence. Journal of Educational Change, 8(4), 337-347. https://doi.org/10.1007/s10833-007-9048-4

Harris, D. N., \& Larsen, M. F. (2016). The effects of the New Orleans post-Katrina school reforms on student academic outcomes (Technical Report). https://educationresearchalliancenola.org/files/publications/ The-Effects-of-the-New-Orleans-Post-Katrina-School-Reforms-on-Student-Academic-Outcomes.pdf

Hatch, T., Hill, K., \& Roegman, R. (2016). Investigating the role of instructional rounds in the development of social networks and district-wide improvement. American Educational Research Journal, 53(4), 1022-1053. https://doi.org/10.3102/0002831216653205

Hill, P. T., Campbell, C., \& Gross, B. (2013). Strife and progress: Portfolio strategies for managing urban schools. Brookings Institution Press. 
Honig, M. I. (2012). District central office leadership as teaching: How central office administrators support principals' development as instructional leaders. Educational Administration Quarterly, 48(4), 733-774. https://doi.org/10.1177/0013161X12443258

Honig, M. I., \& Rainey, L. R. (2014). Central office leadership in principal professional learning communities: The practice beneath the policy. Teachers College Record, 116(4), 1-48.

Honig, M. I., Venkateswaran, N., \& McNeil, P. (2017). Research use as learning: The case of fundamental change in school district central offices. American Educational Research Journal, 54(5), 938971. https://doi.org/10.3102/0002831217712466

Ingersoll, R. M., Sirinides, P., \& Dougherty, P. (2018). Leadership matters: Teachers' roles in school decision making and school performance. https://files.eric.ed.gov/fulltext/EJ1173452.pdf

Jacobson, S. L., Johnson, L., Ylimaki, R., \& Giles, C. (2009). Sustaining success in an American school: A case for governance change. Journal of Educational Administration, 47(6), 753-764. https:/doi.org/ 10.1108/09578230910993131

Johnson, S. M., Reinhorn, S. K., Charner-Laird, M., Kraft, M. A., Ng, M., \& Papay, J. P. (2014). Ready to lead, but how? Teachers' experiences in high-poverty urban schools. Teachers College Record, 116(10), 1-50. https://www.ncbi.nlm.nih.gov/pmc/articles/PMC4391200/pdf/nihms670733.pdf

Kemple, J. (2011). Children first and student outcomes: 2003-2010. In J. A. O’Day, C. S. Bitter, \& L. M. Gomez (Eds.), Education reform in New York City: Ambitious change in the nation's most complex school system (pp. 255-292). Harvard Education Press.

Lake, R. J., \& Hill, P. T. (2009). Performance management in portfolio school districts. https://files.eric .ed.gov/fulltext/ED532895.pdf

Lavallée, P., \& Beaumont, J.-F. (2015). Why we should put some weight on weights. Survey Insights: Methods from the Field, Weighting: Practical Issues and "How to" Approach. https:/surveyinsights.org/ $? \mathrm{p}=6255$

Lee, A. N., \& Nie, Y. (2014). Understanding teacher empowerment: Teachers' perceptions of principal's and immediate supervisor's empowering behaviours, psychological empowerment and work-related outcomes. Teaching and Teacher Education, 41, 67-79. https://doi.org/10.1016/j.tate .2014.03.006

Leithwood, K., \& Jantzi, D. (2008). Linking leadership to student learning: The contributions of leader efficacy. Educational Administration Quarterly, 44(4), 496-528. https://doi.org/10.1177/0013161X08321501

Leithwood, K., \& Mascall, B. (2008). Collective leadership effects on student achievement. Educational Administration Quarterly, 44(4), 529-561. https://doi.org/10.1177/0013161X08321221

Little, J. W. (2006). Professional community and professional development in the learning-centered school. http://www.nea.org/assets/docs/HE/mf_pdreport.pdf

Louis, K. S., Dretzke, B., \& Wahlstrom, K. (2010). How does leadership affect student achievement? Results from a national US survey. School Effectiveness and School Improvement, 21(3), 315-336. https://doi.org/10.1080/09243453.2010.486586

Louis, K. S., Leithwood, K., Wahlstrom, K. L., Anderson, S. E., Michlin, M., Mascall, B., Gordon, M., Strauss, T., Thomas, E., \& Moore, S. (2010). Learning from leadership: Investigating the links to improved student learning. https:/www.wallacefoundation.org/knowledge-center/Documents/Investigating-the-Links-to-Improved-Student-Learning-Executive-Summary.pdf

Marks, H. M., \& Printy, S. M. (2003). Principal leadership and school performance: An integration of transformational and instructional leadership. Educational Administration Quarterly, 39(3), 370397. https://doi.org/10.1177/0013161X03253412 
McEachin, A. J., Welsh, R. O., \& Brewer, D. J. (2016). The variation in student achievement and behavior within a portfolio management model: Early results from New Orleans. Educational Evaluation and Policy Analysis, 38(4), 669-691. https://doi.org/10.3102/0162373716659928

Miles, M. B., \& Huberman, M. (1994). Qualitative data analysis: An expanded sourcebook. Sage.

Miles, M. B., \& Louis, K. S. (1990). Mustering the will and skill for change. Educational Leadership, 47(8), 57-61. https://pdfs.semanticscholar.org/bebc/54 c560e15f1106040789e6563cb9972d750b.pdf

Murphy, J., Elliott, S. N., Goldring, E., \& Porter, A. C. (2007). Leadership for learning: A researchbased model and taxonomy of behaviors. School Leadership \& Management, 27(2), 179-201. https:// doi.org/10.1080/13632430701237420

Neumerski, C. M. (2013). Rethinking instructional leadership, a review: What do we know about principal, teacher, and coach instructional leadership, and where should we go from here? $E d u-$ cational Administration Quarterly, 49(2), 310-347. https://doi.org/10.1177/0013161X12456700

Ni, Y., Yan, R., \& Pounder, D. (2018). Collective leadership: Principals' decision influence and the supportive or inhibiting decision influence of other stakeholders. Educational Administration Quarterly, 54(2), 216-248. https://doi. org/10.1177/0013161X17723427

Pereira, D. G., Afonso, A., \& Medeiros, F. M. (2015). Overview of Friedman's test and post-hoc analysis. Communications in Statistics-Simulation and Computation, 44(10), 2636-2653. https://doi.org/ 10.1080/03610918.2014.931971

Robinson, V. M., Lloyd, C. A., \& Rowe, K. J. (2008). The impact of leadership on student outcomes: An analysis of the differential effects of leadership types. Educational Administration Quarterly, 44(5), 635-674. https://doi.org/10.1177/0013161X08321509

Roch, C. H., \& Sai, N. (2018). Stay or go? Turnover in CMO, EMO and regular charter schools. Social Science Journal, 55(3), 232-244. https://doi.org/10.1016/j.soscij.2018.02.016

Ronfeldt, M., Farmer, S. O., McQueen, K., \& Grissom, J. A. (2015). Teacher collaboration in instructional teams and student achievement. American Educational Research Journal, 52(3), 475-514. https:// doi.org/10.3102/000283121558 5562

Rorrer, A. K., Skrla, L., \& Scheurich, J. J. (2008). Districts as institutional actors in educational reform. Educational Administration Quarterly, 44(3), 307-357. https://doi.org/10.1177/0013161X08318962

Seawell, M., \& Alessi, B.(2018). Denver's luminary learning network shows how innovation zones can work for teachers, students, and families. https:/www.the74million.org/article/denvers-luminary-learningnetwork-shows-how-innovation-zones-can-work-for-teachers-students-and-families/

Sebastian, J., Huang, H., \& Allensworth, E. (2016). The role of teacher leadership in how principals influence classroom instruction and student learning. American Journal of Education, 123(1), 69-108. https://doi.org/10.1086/688169

Sheppard, B. (1996). Exploring the transformational nature of instructional leadership. Alberta Journal of Educational Research, 42(4), 325-344.

Spillane, J. P. (2006). Distributed leadership. Jossey-Bass.

Strunk, K. O., Marsh, J. A., Hashim, A. K., \& Bush-Mecenas, S. (2016). Innovation and a return to the status quo: A mixed-methods study of school reconstitution. Educational Evaluation and Policy Analysis, 38(3), 549-577. https://doi.org/10.3102/0162373716642517

Torres, A. C. (2014). "Are we architects or construction workers?" Re-examining teacher autonomy and turnover in charter schools. Education Policy Analysis Archives, 22, 124. http://dx.doi.org/ 10.14507/epaa.v22.1614

Torres, A. C. (2016). Is this work sustainable? Teacher turnover and perceptions of workload in charter management organizations. Urban Education, 51(8), 891-914. 
Torres, A. C., Bulkley, K., Hashim, A., Marsh, J., Woodward, S., Strunk, K. S., \& Harris, D. (April, 2018). From Central Office to Portfolio Manager: System Change through the Mechanisms of the Portfolio Management Model. Paper presented at the American Educational Research Association (AERA) Annual Meeting: New York, NY.

Torres, A. C., Bulkley, K., \& McCotter, S. (2018). Learning to Lead in Externally Managed and Standalone Charter Schools: How Principals Perceive Their Preparation and Support. International Journal of Leadership in Education, 22(3), 261-278. https://doi.org/10.1080/13603124.2018 .1450994

Torres, D. G. (2019). Distributed leadership, professional collaboration, and teachers' job satisfaction in U.S. schools. Teaching and Teacher Education, 79, 111-123. https://doi.org/10.1016/j.tate.2018 .12 .001

Tushman, M., Maclay, C., \& Herman, K. (2016). Denver public schools 2015: Innovation and performance. http://pelp.fas.harvard.edu/files/hbs-test/files/pel076p2.pdf

Urick, A. (2016). Examining US principal perception of multiple leadership styles used to practice shared instructional leadership. Journal of Educational Administration, 54(2), 152-172. https://doi.org/ 10.1108/JEA-07-2014-0088

Urick, A., \& Bowers, A. J. (2014). What are the different types of principals across the United States? A latent class analysis of principal perception of leadership. Educational Administration Quarterly, 50(1), 96-134. https://doi.org/10.1177/0013161X13489019

Weiss, C. H., Cambone, J., \& Wyeth, A. (1992). Trouble in paradise: Teacher conflicts in shared decision making. Educational Administration Quarterly, 28(3), 350-367. https://doi.org/10.1177/0013161 X92028003007

Wood, D. (2007). Teachers' learning communities: Catalyst for change or a new infrastructure for the status quo? Teachers College Record, 109(3), 699-739.

Yin, R. K. (2013). Case study research: Design and methods (5th ed.). Sage.

\section{Author Biographies}

A. Chris Torres is an assistant professor of K-12 Educational Administration at Michigan State University. He studies urban and low-income school improvement efforts related to school choice, leadership, school turnaround, charter schools, and educator retention and turnover.

Katrina Bulkley is professor of Educational Leadership at Montclair State University. She studies educational leadership, policy, and governance change in urban school systems, with a focus on market-based reform ideas.

Taeyeon Kim is a PhD candidate in K-12 educational administration in the College of Education at Michigan State University. Her research interests include leadership development and learning, the intersection of accountability policies and leadership, and the links between education and social change. 


\section{APPENDIX}

Post hoc test using Hochberg (Model: 1=TPS, 2=Innovation, 3=CMO, 4=Standalone)

\begin{tabular}{|c|c|c|c|c|c|c|}
\hline Category & Dependent Variable & (I) model & (J) model & $\begin{array}{c}\text { Mean } \\
\text { Difference } \\
(\mathrm{I}-\mathrm{J}) \\
\end{array}$ & Std. Error & Sig. \\
\hline \multirow{33}{*}{$\begin{array}{l}\text { Peer Support for } \\
\text { instructional } \\
\text { improvement }\end{array}$} & \multirow[t]{12}{*}{ Analyze data } & \multirow[t]{3}{*}{1} & 2 & $-.054^{*}$ & .018 & .017 \\
\hline & & & 3 & $.248^{*}$ & .019 & .000 \\
\hline & & & 4 & $.247^{*}$ & .024 & .000 \\
\hline & & \multirow[t]{3}{*}{2} & 1 & $.054^{*}$ & .018 & .017 \\
\hline & & & 3 & $.302^{*}$ & .023 & .000 \\
\hline & & & 4 & $.301^{*}$ & .027 & .000 \\
\hline & & \multirow[t]{3}{*}{3} & 1 & $-.248^{*}$ & .019 & .000 \\
\hline & & & 2 & $-.302^{*}$ & .023 & .000 \\
\hline & & & 4 & -.001 & .028 & 1.000 \\
\hline & & \multirow[t]{3}{*}{4} & 1 & $-.247^{*}$ & .024 & .000 \\
\hline & & & 2 & $-.301^{*}$ & .027 & .000 \\
\hline & & & 3 & .001 & .028 & 1.000 \\
\hline & \multirow[t]{12}{*}{ Practice } & \multirow[t]{3}{*}{1} & 2 & -.003 & .017 & 1.000 \\
\hline & & & 3 & .025 & .018 & .676 \\
\hline & & & 4 & $.124^{*}$ & .023 & .000 \\
\hline & & \multirow[t]{3}{*}{2} & 1 & .003 & .017 & 1.000 \\
\hline & & & 3 & .028 & .022 & .726 \\
\hline & & & 4 & $.127^{*}$ & .026 & .000 \\
\hline & & \multirow[t]{3}{*}{3} & 1 & -.025 & .018 & .676 \\
\hline & & & 2 & -.028 & .022 & .726 \\
\hline & & & 4 & $.099^{*}$ & .026 & .001 \\
\hline & & \multirow[t]{3}{*}{4} & 1 & $-.124^{*}$ & .023 & .000 \\
\hline & & & 2 & $-.127^{*}$ & .026 & .000 \\
\hline & & & 3 & $-.099^{*}$ & .026 & .001 \\
\hline & \multirow[t]{9}{*}{ Met coach } & \multirow[t]{3}{*}{1} & 2 & $-.132^{*}$ & .019 & .000 \\
\hline & & & 3 & $-.277^{*}$ & .019 & .000 \\
\hline & & & 4 & $.276^{*}$ & .025 & .000 \\
\hline & & \multirow[t]{3}{*}{2} & 1 & $.132^{*}$ & .019 & .000 \\
\hline & & & 3 & $-.145^{*}$ & .023 & .000 \\
\hline & & & 4 & $.408^{*}$ & .028 & .000 \\
\hline & & \multirow[t]{3}{*}{3} & 1 & $.277^{*}$ & .019 & .000 \\
\hline & & & 2 & $.145^{*}$ & .023 & .000 \\
\hline & & & 4 & $.553^{*}$ & .028 & .000 \\
\hline
\end{tabular}




\begin{tabular}{|c|c|c|c|c|c|c|}
\hline & & \multirow[t]{3}{*}{4} & 1 & $-.276^{*}$ & .025 & .000 \\
\hline & & & 2 & $-.408^{*}$ & .028 & .000 \\
\hline & & & 3 & $-.553^{*}$ & .028 & .000 \\
\hline & \multirow[t]{12}{*}{ Observation } & \multirow[t]{3}{*}{1} & 2 & -.018 & .015 & .787 \\
\hline & & & 3 & $-.152^{*}$ & .015 & .000 \\
\hline & & & 4 & .050 & .020 & .058 \\
\hline & & \multirow[t]{3}{*}{2} & 1 & .018 & .015 & .787 \\
\hline & & & 3 & $-.135^{*}$ & .019 & .000 \\
\hline & & & 4 & $.068^{*}$ & .022 & .012 \\
\hline & & \multirow[t]{3}{*}{3} & 1 & $.152^{*}$ & .015 & .000 \\
\hline & & & 2 & $.135^{*}$ & .019 & .000 \\
\hline & & & 4 & $.203^{*}$ & .023 & .000 \\
\hline & & \multirow[t]{3}{*}{4} & 1 & -.050 & .020 & .058 \\
\hline & & & 2 & $-.068^{*}$ & .022 & .012 \\
\hline & & & 3 & $-.203^{*}$ & .023 & .000 \\
\hline & \multirow[t]{12}{*}{ Student needs } & \multirow[t]{3}{*}{1} & 2 & $-.297^{*}$ & .047 & .000 \\
\hline & & & 3 & $-.414^{*}$ & .049 & .000 \\
\hline & & & 4 & .098 & .062 & .519 \\
\hline & & \multirow[t]{3}{*}{2} & 1 & $.297^{*}$ & .047 & .000 \\
\hline & & & 3 & -.117 & .059 & .254 \\
\hline & & & 4 & $.395^{*}$ & .071 & .000 \\
\hline & & \multirow[t]{3}{*}{3} & 1 & $.414^{*}$ & .049 & .000 \\
\hline & & & 2 & .117 & .059 & .254 \\
\hline & & & 4 & $.512^{*}$ & .072 & .000 \\
\hline & & \multirow[t]{3}{*}{4} & 1 & -.098 & .062 & .519 \\
\hline & & & 2 & $-.395^{*}$ & .071 & .000 \\
\hline & & & 3 & $-.512^{*}$ & .072 & .000 \\
\hline \multirow{10}{*}{$\begin{array}{l}\text { Principal } \\
\text { instructional } \\
\text { leadership and } \\
\text { coordination/support }\end{array}$} & \multirow[t]{10}{*}{ Standards } & \multirow[t]{3}{*}{1} & 2 & -.004 & .030 & 1.000 \\
\hline & & & 3 & $-.086^{*}$ & .031 & .030 \\
\hline & & & 4 & $.277^{*}$ & .041 & .000 \\
\hline & & \multirow[t]{3}{*}{2} & 1 & .004 & .030 & 1.000 \\
\hline & & & 3 & -.082 & .037 & .148 \\
\hline & & & 4 & $.281^{*}$ & .046 & .000 \\
\hline & & \multirow[t]{3}{*}{3} & 1 & $.086^{*}$ & .031 & .030 \\
\hline & & & 2 & .082 & .037 & .148 \\
\hline & & & 4 & $.363^{*}$ & .047 & .000 \\
\hline & & 4 & 1 & $-.277^{*}$ & .041 & .000 \\
\hline
\end{tabular}




\begin{tabular}{|c|c|c|c|c|c|}
\hline & & 2 & $-.281^{*}$ & .046 & .000 \\
\hline & & 3 & $-.363^{*}$ & .047 & .000 \\
\hline \multirow[t]{12}{*}{ Resource } & \multirow[t]{3}{*}{1} & 2 & -.031 & .033 & .927 \\
\hline & & 3 & -.036 & .035 & .886 \\
\hline & & 4 & $.249^{*}$ & .046 & .000 \\
\hline & \multirow[t]{3}{*}{2} & 1 & .031 & .033 & .927 \\
\hline & & 3 & -.005 & .042 & 1.000 \\
\hline & & 4 & $.280^{*}$ & .052 & .000 \\
\hline & \multirow[t]{3}{*}{3} & 1 & .036 & .035 & .886 \\
\hline & & 2 & .005 & .042 & 1.000 \\
\hline & & 4 & $.285^{*}$ & .053 & .000 \\
\hline & \multirow[t]{3}{*}{4} & 1 & $-.249^{*}$ & .046 & .000 \\
\hline & & 2 & $-.280^{*}$ & .052 & .000 \\
\hline & & 3 & $-.285^{*}$ & .053 & .000 \\
\hline \multirow[t]{12}{*}{ PD } & \multirow[t]{3}{*}{1} & 2 & .009 & .032 & 1.000 \\
\hline & & 3 & -.001 & .033 & 1.000 \\
\hline & & 4 & $.204^{*}$ & .044 & .000 \\
\hline & \multirow[t]{3}{*}{2} & 1 & -.009 & .032 & 1.000 \\
\hline & & 3 & -.010 & .040 & 1.000 \\
\hline & & 4 & $.195^{*}$ & .049 & .000 \\
\hline & \multirow[t]{3}{*}{3} & 1 & .001 & .033 & 1.000 \\
\hline & & 2 & .010 & .040 & 1.000 \\
\hline & & 4 & $.205^{*}$ & .050 & .000 \\
\hline & \multirow[t]{3}{*}{4} & 1 & $-.204^{*}$ & .044 & .000 \\
\hline & & 2 & $-.195^{*}$ & .049 & .000 \\
\hline & & 3 & $-.205^{*}$ & .050 & .000 \\
\hline \multirow[t]{12}{*}{ Quality } & \multirow[t]{3}{*}{1} & 2 & .044 & .035 & .751 \\
\hline & & 3 & -.047 & .036 & .733 \\
\hline & & 4 & $.403^{*}$ & .048 & .000 \\
\hline & \multirow[t]{3}{*}{2} & 1 & -.044 & .035 & .751 \\
\hline & & 3 & -.091 & .044 & .206 \\
\hline & & 4 & $.359^{*}$ & .054 & .000 \\
\hline & \multirow[t]{3}{*}{3} & 1 & .047 & .036 & .733 \\
\hline & & 2 & .091 & .044 & .206 \\
\hline & & 4 & $.450^{*}$ & .055 & .000 \\
\hline & \multirow[t]{3}{*}{4} & 1 & $-.403^{*}$ & .048 & .000 \\
\hline & & 2 & $-.359^{*}$ & .054 & .000 \\
\hline & & 3 & $-.450^{*}$ & .055 & .000 \\
\hline
\end{tabular}




\begin{tabular}{|c|c|c|c|c|c|c|}
\hline & \multirow[t]{12}{*}{ Coaching } & \multirow[t]{3}{*}{1} & 2 & -.053 & .037 & .633 \\
\hline & & & 3 & $-.146^{*}$ & .039 & .001 \\
\hline & & & 4 & $.345^{*}$ & .051 & .000 \\
\hline & & \multirow[t]{3}{*}{2} & 1 & .053 & .037 & .633 \\
\hline & & & 3 & -.094 & .046 & .234 \\
\hline & & & 4 & $.398^{*}$ & .057 & .000 \\
\hline & & \multirow[t]{3}{*}{3} & 1 & $.146^{*}$ & .039 & .001 \\
\hline & & & 2 & .094 & .046 & .234 \\
\hline & & & 4 & $.492^{*}$ & .058 & .000 \\
\hline & & \multirow[t]{3}{*}{4} & 1 & $-.345^{*}$ & .051 & .000 \\
\hline & & & 2 & $-.398^{*}$ & .057 & .000 \\
\hline & & & 3 & $-.492^{*}$ & .058 & .000 \\
\hline & \multirow[t]{12}{*}{ Accodviceuntable } & \multirow[t]{3}{*}{1} & 2 & .039 & .031 & .748 \\
\hline & & & 3 & $-.105^{*}$ & .032 & .006 \\
\hline & & & 4 & $.428^{*}$ & .042 & .000 \\
\hline & & \multirow[t]{3}{*}{2} & 1 & -.039 & .031 & .748 \\
\hline & & & 3 & $-.144^{*}$ & .038 & .001 \\
\hline & & & 4 & $.390^{*}$ & .047 & .000 \\
\hline & & \multirow[t]{3}{*}{3} & 1 & $.105^{*}$ & .032 & .006 \\
\hline & & & 2 & $.144^{*}$ & .038 & .001 \\
\hline & & & 4 & $.534^{*}$ & .048 & .000 \\
\hline & & \multirow[t]{3}{*}{4} & 1 & $-.428^{*}$ & .042 & .000 \\
\hline & & & 2 & $-.390^{*}$ & .047 & .000 \\
\hline & & & 3 & $-.534^{*}$ & .048 & .000 \\
\hline \multirow{14}{*}{$\begin{array}{l}\text { School climate of } \\
\text { collaboration }\end{array}$} & \multirow[t]{12}{*}{ Share } & \multirow[t]{3}{*}{1} & 2 & $.080^{*}$ & .026 & .011 \\
\hline & & & 3 & $-.150^{*}$ & .027 & .000 \\
\hline & & & 4 & $.137^{*}$ & .034 & .000 \\
\hline & & \multirow[t]{3}{*}{2} & 1 & $-.080^{*}$ & .026 & .011 \\
\hline & & & 3 & $-.230^{*}$ & .033 & .000 \\
\hline & & & 4 & .057 & .039 & .602 \\
\hline & & \multirow[t]{3}{*}{3} & 1 & $.150^{*}$ & .027 & .000 \\
\hline & & & 2 & $.230^{*}$ & .033 & .000 \\
\hline & & & 4 & $.287^{*}$ & .040 & .000 \\
\hline & & \multirow[t]{3}{*}{4} & 1 & $-.137^{*}$ & .034 & .000 \\
\hline & & & 2 & -.057 & .039 & .602 \\
\hline & & & 3 & $-.287^{*}$ & .040 & .000 \\
\hline & \multirow[t]{2}{*}{ Advice } & \multirow[t]{2}{*}{1} & 2 & -.007 & .024 & 1.000 \\
\hline & & & 3 & $-.142^{*}$ & .026 & .000 \\
\hline
\end{tabular}




\begin{tabular}{|c|c|c|c|c|c|}
\hline & & 4 & -.039 & .033 & .791 \\
\hline & \multirow[t]{3}{*}{2} & 1 & .007 & .024 & 1.000 \\
\hline & & 3 & $-.135^{*}$ & .031 & .000 \\
\hline & & 4 & -.033 & .037 & .942 \\
\hline & \multirow[t]{3}{*}{3} & 1 & $.142^{*}$ & .026 & .000 \\
\hline & & 2 & $.135^{*}$ & .031 & .000 \\
\hline & & 4 & $.103^{*}$ & .038 & .038 \\
\hline & \multirow[t]{3}{*}{4} & 1 & .039 & .033 & .791 \\
\hline & & 2 & .033 & .037 & .942 \\
\hline & & 3 & $-.103^{*}$ & .038 & .038 \\
\hline \multirow[t]{12}{*}{ Trust } & \multirow[t]{3}{*}{1} & 2 & $-.112^{*}$ & .027 & .000 \\
\hline & & 3 & $-.314^{*}$ & .028 & .000 \\
\hline & & 4 & $-.153^{*}$ & .035 & .000 \\
\hline & \multirow[t]{3}{*}{2} & 1 & $.112^{*}$ & .027 & .000 \\
\hline & & 3 & $-.202^{*}$ & .034 & .000 \\
\hline & & 4 & -.041 & .040 & .891 \\
\hline & \multirow[t]{3}{*}{3} & 1 & $.314^{*}$ & .028 & .000 \\
\hline & & 2 & $.202^{*}$ & .034 & .000 \\
\hline & & 4 & $.161^{*}$ & .041 & .000 \\
\hline & \multirow[t]{3}{*}{4} & 1 & $.153^{*}$ & .035 & .000 \\
\hline & & 2 & .041 & .040 & .891 \\
\hline & & 3 & $-.161^{*}$ & .041 & .000 \\
\hline \multirow[t]{12}{*}{ Discuss } & \multirow[t]{3}{*}{1} & 2 & $-.132^{*}$ & .029 & .000 \\
\hline & & 3 & $-.379^{*}$ & .030 & .000 \\
\hline & & 4 & $-.333^{*}$ & .038 & .000 \\
\hline & \multirow[t]{3}{*}{2} & 1 & $.132^{*}$ & .029 & .000 \\
\hline & & 3 & $-.247^{*}$ & .036 & .000 \\
\hline & & 4 & $-.201^{*}$ & .043 & .000 \\
\hline & \multirow[t]{3}{*}{3} & 1 & $.379^{*}$ & .030 & .000 \\
\hline & & 2 & $.247^{*}$ & .036 & .000 \\
\hline & & 4 & .046 & .044 & .870 \\
\hline & \multirow[t]{3}{*}{4} & 1 & $.333^{*}$ & .038 & .000 \\
\hline & & 2 & $.201^{*}$ & .043 & .000 \\
\hline & & 3 & -.046 & .044 & .870 \\
\hline \multirow[t]{4}{*}{ Lead } & \multirow[t]{3}{*}{1} & 2 & $-.193^{*}$ & .027 & .000 \\
\hline & & 3 & $-.525^{*}$ & .028 & .000 \\
\hline & & 4 & $-.399^{*}$ & .035 & .000 \\
\hline & 2 & 1 & $.193^{*}$ & .027 & .000 \\
\hline
\end{tabular}




\begin{tabular}{|c|c|c|c|c|c|c|}
\hline & & & 3 & $-.332^{*}$ & .034 & .000 \\
\hline & & & 4 & $-.206^{*}$ & .040 & .000 \\
\hline & & \multirow[t]{3}{*}{3} & 1 & $.525^{*}$ & .028 & .000 \\
\hline & & & 2 & $.332^{*}$ & .034 & .000 \\
\hline & & & 4 & $.126^{*}$ & .041 & .012 \\
\hline & & \multirow[t]{3}{*}{4} & 1 & $.399^{*}$ & .035 & .000 \\
\hline & & & 2 & $.206^{*}$ & .040 & .000 \\
\hline & & & 3 & $-.126^{*}$ & .041 & .012 \\
\hline & \multirow[t]{12}{*}{ Respect } & \multirow[t]{3}{*}{1} & 2 & $-.168^{*}$ & .026 & .000 \\
\hline & & & 3 & $-.453^{*}$ & .027 & .000 \\
\hline & & & 4 & $-.250^{*}$ & .035 & .000 \\
\hline & & \multirow[t]{3}{*}{2} & 1 & $.168^{*}$ & .026 & .000 \\
\hline & & & 3 & $-.285^{*}$ & .033 & .000 \\
\hline & & & 4 & -.082 & .039 & .206 \\
\hline & & \multirow[t]{3}{*}{3} & 1 & $.453^{*}$ & .027 & .000 \\
\hline & & & 2 & $.285^{*}$ & .033 & .000 \\
\hline & & & 4 & $.203^{*}$ & .040 & .000 \\
\hline & & \multirow[t]{3}{*}{4} & 1 & $.250^{*}$ & .035 & .000 \\
\hline & & & 2 & .082 & .039 & .206 \\
\hline & & & 3 & $-.203^{*}$ & .040 & .000 \\
\hline & \multirow[t]{12}{*}{ Meaning } & \multirow[t]{3}{*}{1} & 2 & $-.147^{*}$ & .026 & .000 \\
\hline & & & 3 & $-.410^{*}$ & .027 & .000 \\
\hline & & & 4 & $-.163^{*}$ & .035 & .000 \\
\hline & & \multirow[t]{3}{*}{2} & 1 & $.147^{*}$ & .026 & .000 \\
\hline & & & 3 & $-.263^{*}$ & .033 & .000 \\
\hline & & & 4 & -.015 & .039 & .999 \\
\hline & & \multirow[t]{3}{*}{3} & 1 & $.410^{*}$ & .027 & .000 \\
\hline & & & 2 & $.263^{*}$ & .033 & .000 \\
\hline & & & 4 & $.247^{*}$ & .040 & .000 \\
\hline & & \multirow[t]{3}{*}{4} & 1 & $.163^{*}$ & .035 & .000 \\
\hline & & & 2 & .015 & .039 & .999 \\
\hline & & & 3 & $-.247^{*}$ & .040 & .000 \\
\hline \multirow{6}{*}{$\begin{array}{l}\text { Teacher participation } \\
\text { in school-wide } \\
\text { decision making }\end{array}$} & \multirow{6}{*}{ Mission } & \multirow[t]{3}{*}{1} & 2 & $-.449^{*}$ & .034 & .000 \\
\hline & & & 3 & $.216^{*}$ & .036 & .000 \\
\hline & & & 4 & $.273^{*}$ & .047 & .000 \\
\hline & & \multirow[t]{3}{*}{2} & 1 & $.449^{*}$ & .034 & .000 \\
\hline & & & 3 & $.664^{*}$ & .043 & .000 \\
\hline & & & 4 & $.721^{*}$ & .053 & .000 \\
\hline
\end{tabular}




\begin{tabular}{|c|c|c|c|c|c|}
\hline & \multirow[t]{3}{*}{3} & 1 & $-.216^{*}$ & .036 & .000 \\
\hline & & 2 & $-.664^{*}$ & .043 & .000 \\
\hline & & 4 & .057 & .054 & .874 \\
\hline & \multirow[t]{3}{*}{4} & 1 & $-.273^{*}$ & .047 & .000 \\
\hline & & 2 & $-.721^{*}$ & .053 & .000 \\
\hline & & 3 & -.057 & .054 & .874 \\
\hline \multirow[t]{12}{*}{ HR } & \multirow[t]{3}{*}{1} & 2 & $-.120^{*}$ & .030 & .000 \\
\hline & & 3 & $.250^{*}$ & .031 & .000 \\
\hline & & 4 & $.764^{*}$ & .041 & .000 \\
\hline & \multirow[t]{3}{*}{2} & 1 & $.120^{*}$ & .030 & .000 \\
\hline & & 3 & $.371^{*}$ & .038 & .000 \\
\hline & & 4 & $.884^{*}$ & .047 & .000 \\
\hline & \multirow[t]{3}{*}{3} & 1 & $-.250^{*}$ & .031 & .000 \\
\hline & & 2 & $-.371^{*}$ & .038 & .000 \\
\hline & & 4 & $.513^{*}$ & .047 & .000 \\
\hline & \multirow[t]{3}{*}{4} & 1 & $-.764^{*}$ & .041 & .000 \\
\hline & & 2 & $-.884^{*}$ & .047 & .000 \\
\hline & & 3 & $-.513^{*}$ & .047 & .000 \\
\hline \multirow[t]{12}{*}{ Budget } & \multirow[t]{3}{*}{1} & 2 & $-.121^{*}$ & .027 & .000 \\
\hline & & 3 & $.248^{*}$ & .028 & .000 \\
\hline & & 4 & $.443^{*}$ & .037 & .000 \\
\hline & \multirow[t]{3}{*}{2} & 1 & $.121^{*}$ & .027 & .000 \\
\hline & & 3 & $.369^{*}$ & .034 & .000 \\
\hline & & 4 & $.564^{*}$ & .042 & .000 \\
\hline & \multirow[t]{3}{*}{3} & 1 & $-.248^{*}$ & .028 & .000 \\
\hline & & 2 & $-.369^{*}$ & .034 & .000 \\
\hline & & 4 & $.194^{*}$ & .042 & .000 \\
\hline & \multirow[t]{3}{*}{4} & 1 & $-.443^{*}$ & .037 & .000 \\
\hline & & 2 & $-.564^{*}$ & .042 & .000 \\
\hline & & 3 & $-.194^{*}$ & .042 & .000 \\
\hline \multirow[t]{7}{*}{ Materials } & \multirow[t]{3}{*}{1} & 2 & $-.349^{*}$ & .035 & .000 \\
\hline & & 3 & $-.458^{*}$ & .036 & .000 \\
\hline & & 4 & $-.139^{*}$ & .048 & .023 \\
\hline & \multirow[t]{3}{*}{2} & 1 & $.349^{*}$ & .035 & .000 \\
\hline & & 3 & -.108 & .044 & .076 \\
\hline & & 4 & $.211^{*}$ & .054 & .001 \\
\hline & 3 & 1 & $.458^{*}$ & .036 & .000 \\
\hline
\end{tabular}




\begin{tabular}{|c|c|c|c|c|c|}
\hline & & 2 & .108 & .044 & .076 \\
\hline & & 4 & $.319^{*}$ & .055 & .000 \\
\hline & \multirow[t]{3}{*}{4} & 1 & $.139^{*}$ & .048 & .023 \\
\hline & & 2 & $-.211^{*}$ & .054 & .001 \\
\hline & & 3 & $-.319^{*}$ & .055 & .000 \\
\hline \multirow[t]{12}{*}{ Course content } & \multirow[t]{3}{*}{1} & 2 & $-.285^{*}$ & .034 & .000 \\
\hline & & 3 & $-.235^{*}$ & .035 & .000 \\
\hline & & 4 & $.126^{*}$ & .048 & .050 \\
\hline & \multirow[t]{3}{*}{2} & 1 & $.285^{*}$ & .034 & .000 \\
\hline & & 3 & .049 & .043 & .823 \\
\hline & & 4 & $.411^{*}$ & .054 & .000 \\
\hline & \multirow[t]{3}{*}{3} & 1 & $.235^{*}$ & .035 & .000 \\
\hline & & 2 & -.049 & .043 & .823 \\
\hline & & 4 & $.362^{*}$ & .054 & .000 \\
\hline & \multirow[t]{3}{*}{4} & 1 & $-.126^{*}$ & .048 & .050 \\
\hline & & 2 & $-.411^{*}$ & .054 & .000 \\
\hline & & 3 & $-.362^{*}$ & .054 & .000 \\
\hline \multirow[t]{12}{*}{ PD content } & \multirow[t]{3}{*}{1} & 2 & $-.179^{*}$ & .031 & .000 \\
\hline & & 3 & -.053 & .032 & .455 \\
\hline & & 4 & $.193^{*}$ & .043 & .000 \\
\hline & \multirow[t]{3}{*}{2} & 1 & $.179^{*}$ & .031 & .000 \\
\hline & & 3 & $.125^{*}$ & .039 & .007 \\
\hline & & 4 & $.371^{*}$ & .048 & .000 \\
\hline & \multirow[t]{3}{*}{3} & 1 & .053 & .032 & .455 \\
\hline & & 2 & $-.125^{*}$ & .039 & .007 \\
\hline & & 4 & $.246^{*}$ & .049 & .000 \\
\hline & \multirow[t]{3}{*}{4} & 1 & $-.193^{*}$ & .043 & .000 \\
\hline & & 2 & $-.371^{*}$ & .048 & .000 \\
\hline & & 3 & $-.246^{*}$ & .049 & .000 \\
\hline
\end{tabular}

